\title{
Furadékminták gáz és illékony komponenseinek vizsgálatához szükséges minta-elôkészítési és -feltárási protokoll fejlesztésének eredményei
}

\author{
KÖRMÖs Sándor*, CZIRBUS Nóra, ScHUBERT Félix
}

SZTE TTIK Ásványtani, Geokémiai és Kőzettani Tanszék, 6722 Szeged, Egyetem utca 2.

*levelező szerző, email: krmssandor@gmail.com

\section{Development of measuring protocol for gas and volatile analysis of drill cuttings}

Abstract

Fluid inclusions trapped in drill cores and cuttings may provide essential information about the ancient fluid system. Information can be obtained about the chemical composition and the vertical dimensions of the fluid system as well as the palaeo-fluid contacts by analysing the gas and volatile compounds of those trapped fluid remnants. Logging the extracted gas and volatile compounds over drill section we can represent the profile of hydrocarbon, non-hydrocarbon and further derived parameters. A gas-analyser was built at the Department of Mineralogy, Geochemistry and Petrology, University of Szeged for analysing fluid inclusions by mechanical decrepitation in a low-pressure and high-temperature crushing chamber. The released compounds are analysed by a quadrupole mass spectrometer connected directly to the crushing chambers.

There are indispensable conditions to examine drill cuttings, such as the sample preparation and the crushing procedure for decrepitating the fluid inclusions at high efficiency. For the reproducible, representative and optimal measurement protocol we performed crushing tests on pre-sieved quartz sand and cleaning tests on pre-contaminated quartz sand. According to the results of crushing tests the amount of sample, hits rate and squeezing time, all modify the crushing efficiency but at different ways. Based on our experiments, in order to mechanically decrepitate fluid inclusions at the highest efficiency $0.5-1.0 \mathrm{~g}$ amount of sample, at least 50 hits and $1 \mathrm{sec}$ squeezing time must be applied.

Comparing the efficiencies of different cleaning procedures it was verified that cleaning of the highly-contaminated drill cuttings with detergent is necessary to get representative analytical results. However, this cleaning procedure significantly rises the duration of sample preparation and hence the measuring time of the individual samples.

Based on the results of tests performed we have developed a measurement protocol for gas analysis of drill cores and cuttings, furthermore have marked out directions of the potential developments.

Keywords: gas-analyser, cuttings cleaning procedures, crushing tests, fluid-inclusion stratigraphy

\section{Összefoglalás}

A mélyfúrásokból származó fúrómagok, furadékminták anyagában csapdázódott fluidumzárványok gáz és illékony komponens tartalmának vizsgálatával lehetőség nyílik a kőzettestben egykor múködött fluidumrendszerek kémiai összetételének megismerésére, azok vertikális kiterjedésének meghatározására, a paleo-fázishatárok lehatárolására. A kiválasztott fúrásszelvény mentén, a kőzetmintákból kiszabadított gázok relatív mennyiségét a mélység függvényében ábrázolva, gázprofilok, illetve ezekből további származtatott paraméterek számíthatók. A Szegedi Tudományegyetem Ásványtani, Geokémiai és Kőzettani Tanszékén megépített gázanalizátorral a fluidumzárványok mechanikai feltárása (,feltörése”) alacsony nyomású - magas hőmérsékletű körülmények között történik. Az így felszabadított gázok azonosítását a törőkamrákhoz csatlakoztatott kvadrupól tömegspektrométerrel végezzük.

A furadékminták vizsgálatának elengedhetetlen feltétele a minták megfelelő előtisztítása, majd a fluidumzárványok hatékony és reprodukálható feltárása, azaz a minta törése. Az optimális mérési protokoll kialakítása céljából, az adatok reprodukálhatósága és megbízhatósága érdekében a múszer törőegységeivel 250-500 ㅆm mérettartományba esố kvarchomok minták töréstesztjeit, és eltérő típusú fúróiszapokkal szennyezett kvarchomok minták tisztítási eljárásait vizsgáltuk meg. A töréstesztek eredményei alapján a nagyobb mintamennyiség, a magasabb ütésszám vagy a megnövelt préselési idő eltérő mértékben módosítja az aprózódás hatékonyságát. Vizsgálataink alapján az optimális aprózódás, azaz a legnagyobb számú fluidumzárvány felnyitásához maximálisan 0,5-1,0 g mintamennyiség, minimum 50 db ütésszám és 1 sec ütésenkénti préselési idő szükséges.

A tisztítási eljárások hatékonyságának összehasonlítása során beigazolódott, hogy a megvizsgált tisztítási módszerek esetében, a minták mosószeres tisztítása a minta-előkészítés időtartamát jelentősen megnöveli, de bizonyos 
minták esetében a mosás alkalmazása elkerülhetetlen a megbízható mérési eredmény elérése érdekében. Az elvégzett tesztek eredményei alapján kidolgoztuk a múszer kőzet- és furadékminták vizsgálatára alkalmazható mérési protokollját, továbbá meghatároztuk a további fejlesztési irányokat.

Tárgyszavak: gázanalizátor, eltérô furadékminta tisztítási eljárások, töréstesztek, fluidumzárvány-sztratigráfia

\section{Bevezetés}

Fluidumzárványnak nevezünk — mennyiségtől és mérettôl függetlenül — bármilyen egy- vagy többfázisú fluidummaradványt, amely kristályos vagy amorf anyagba bezáródva fordul elő (SCHUBERT et al. 2007). A fluidumzárványok megőrizhetik a csapdázódáskor uralkodó fluidumrendszer fiziko-kémiai tulajdonságait és közvetlen információt nyújthatnak az évmilliókkal korábban lezajlott fluidum-migrációs események körülményeirôl. A fluidumzárványok — összetételüket tekintve — leggyakrabban vizes zárványok, amelyek gyakran tartalmaznak különböző szervetlen és szerves gázokat (pl. szén-dioxid, metán, hidrogén, nitrogén, kénhidrogén, kén-dioxid), illetve nagyobb szénatomszámú szénhidrogéneket (SALVI \& WiLliAMS-Jones 2003). A fluidumzárványok kémiai összetételének meghatározása roncsolásmentes és roncsolásos (destruktív) analitikai módszerekkel történhet. A legelterjedtebb roncsolásmentes analitikai eljárások közé tartozik a mikrotermometria (a zárványban lejátszódó fázisátalakulások hőmérsékletének meghatározása), a fluoreszcens-, Raman-, illetve Fouriertranszformációs infravörös spektroszkópia vagy a mágneses magrezonancia vizsgálatok (Munz 2001, SAMSON et al. 2003, HurAi et al. 2015). A roncsolásmentes technológiák hátránya — többek között — azok viszonylag magas kimutatási határa, a Raman spektroszkópia esetében a lézer indukálta fluoreszcencia jelensége. Ezenfelül az adott módszer támasztotta egyedi peremfeltételek szükséges megléte, mint például a mikrotermometria esetében minimális fluidumzárvány-méret vagy a fluoreszcens spektroszkópia alkalmazása során a fluoreszcencia hiánya (SALVI \& WiLliams-Jones 2003). A teljes (bulk) minta roncsolásos analitikai vizsgálatával az alacsony koncentrációban előforduló komponensek kimutatására is lehetôség nyílik, azonban alkalmazása során figyelembe kell venni, hogy a mintában jelenlévő fluidumzárvány-együttesek vizsgálata — az alkalmazott feltárási módszertől függően — akár együttesen is megvalósulhat, amely így a mérés során az eltérő fluidumzárvány-együttesek fluidum tartalmának összekeveredésével járhat (SALVi \& WiLliams-Jones 2003). A kőzetmintákba zárt fluidumzárványok felnyitását követően, azok kémiai összetételének meghatározása önálló tömegspektrometriás (Mass Spectrometer - MS) (BARCLAY et al. 2000, Brewster \& Hall 2001, PARnel et al. 2001, Dilley \& NORMAN 2007, LIVSEY et al. 2014), gázkromatográfiával (Gas Chromatography - Mass Spectrometry - GC-MS) (LiSK et al. 1996, VoLK et al. 2002, GEORGE et al. 2002, GEORGE \& AHMED 2002) vagy nagyhatékonyságú folyadékkromatográfiával kapcsolt tömegspektrometriás mérések (High Performance Liquid Chromatography - Mass Spectrometry - HPLC-MS) (PANG et al. 1998) elvégzésével lehetséges. A legalacsonyabb — akár nanogramm nagyság- rendú - kimutatási határ a tömegspektrometriás mérési módszerekkel érhető el (NoRmAn \& Musgrave 1994, SALVI \& Williams-Jones 2003). A közvetett (off-line) eljárás során a fluidumzárványok felnyitását követően, az illó komponensek dúsítása (pl. adszorbeálása) történik, majd ezt követően kerülnek a mérőmúszerbe (SALVI \& WILLIAMSJONES 2003, GEORGE et al. 2007). A közvetlen (on-line) mérés során az illó komponenseket — a felszabadítást követően — dúsítás nélkül, közvetlenül a mérőmúszerbe juttatják (ANDREWs \& GIBSON 1979, BARKER \& SMITH 1986, Bray et al. 1991, Graney et al. 1991, MoORE et al. 2001, SAlvi \& Williams-Jones 2003, Ahmed \& GeORge 2004, GEORGE et al. 2007).

Különböző rétegtani helyzetben megjelenő kőzetek fluidumzárványainak kémiai összetétele eltérô lehet, amelyeket szelvény mentén vizsgálva az egykori fluidumrendszerre jellemző információkhoz juthatunk. A kőzetminták tömegspektrometriás vizsgálta a nemzetközi irodalom szerint a fluidumzárvány-sztratigráfia (Fluid Inclusion Stratigraphy - FIS), amit az olajiparban többek között paleomigráció, záró rétegek vagy paleo-fluidumrendszer fázishatárainak azonosításában alkalmaznak (BARCLAY et al. 2000, Brewster \& HALl 2001, PARnel et al. 2001, LiU et al. 2003, Livsey et al. 2014, MirandA et al. 2013). A geotermikus célú kutatások során a FIS módszer a különböző fluidum források eredményeként kialakult eltérő kémiai összetétel és a komponensekből képzett aránypárok meghatározásával, értelmezésével a felszín alatti víz meteorikus vagy hidrotermás eredetének azonosításában használható (DiLley \& NoRman 2005). Az érckutatásban a hidrotermális rendszer eredetének és kapcsolatrendszerének feltárásában nyújthat információt (NORMAN \& MuSGRAVE 1994, Norman et al. 1996, Moore et al. 2001, Blamey 2012, AZMY \& Blamey 2013).

Munkánkban a Szegedi Tudományegyetem, Ásványtani, Geokémiai és Kőzettani Tanszékén múködő, destruktív, dúsítást nélkülöző, tömegspektrometriás mérési módszeren alapuló gázanalizátor furadékmintákra kidolgozott minta-előkészítési és -feltárási protokolljának kifejlesztését mutatjuk be. A furadékminták illékony komponenseinek minőségi és mennyiségi összetételére vonatkozó adatok megbízhatósága és reprodukálhatósága érdekében, töréstesztek és tisztítási eljárások eredményeit felhasználva, kidolgoztuk a múszer furadékminták vizsgálatára alkalmazható mérési protokollját. A gázanalizátorral nagyszámú minta gyors mérése végezhetô el, ezáltal mód nyílik az egyes mélységintervallumokat reprezentáló furadékminták gáz és illékony komponenseinek fúrásszelvény menti öszszehasonlítására. A szénhidrogén-kutatás során, a kőzetminták szerves geokémiai jellemzésére általánosan alkalmazott Rock-Eval (RE) pirolízis eljárás optimális esetben a minták fúrást követô mielőbbi vizsgálatához használatos. 
Mivel a gázanalizátorral vizsgált gáz és illékony komponensek fluidumzárványokban csapdázódtak, így nincsenek kitéve a minta szakszerútlen vagy hosszú idejú tárolása során bekövetkező oxidatív és evaporatív veszteségnek, amely változások hatással lehetnek a RE pirolízissel kapott adatok megbízhatóságára (HART \& STEEN 2015). A RE pirolízishez képest a FIS eljárás mintatárolás szempontjából alacsonyabb igényszintje tovább növeli a módszer szénhidrogénkutatási célú alkalmazhatóságát.

\section{Fluidumzárványok közvetlen vizsgálatának kutatástörténeti áttekintése}

Az elsô tudományos értékú fluidumzárvány leírást ABU RAIHAN AL-BIRUNIA közölte a XI. században (KESLER et al. 2013), azonban a fluidumzárványok összetételének meghatározására egészen a XIX. századig várni kellett (RoedDer 1972, Kesler et al. 2013, HurAi et al. 2015). Fluidumzárványok kémiai összetételének vizsgálatát elsőként DAVY (1822) végezte el, aki — többek között — Selmecbányáról származó ásványok fluidumzárványainak összetételét határozta meg, azok desztillált víz, higany vagy olaj alatti, fúrással történt felszabadítását követően. SORBY (1858) vizsgálataival igazolta, hogy a fluidumzárványok döntôen vizes zárványok, amit a hőmérséklet növelése során bekövetkező dekrepitációkor felszabaduló gôz kondenzálását és fagyasztását követően határozott meg. KARPINSKY szén-dioxid zárványok vizsgálatát végezte, amely során az ásványszemcséket higanyban ôrölte, majd a felszabaduló szén-dioxidot $\mathrm{Ba}(\mathrm{OH})_{2}$ oldattal alkotott csapadékából azonosította (HURAI et al. 2015). WRIGHT (1881) kivákuumozott mintatérben termikus dekrepitációt alkalmazott, majd ezt követően vizsgálta a feltárt fluidumzárványok összetételét.

A XX. század közepén — többek között — KALYUZHNYI vagy MASLOVA munkáiban még elterjedt eljárás volt a nagyméretû fluidumzárványok fúrása vagy a befoglaló ásvány őrlése, amelyek esetében a zárvány tartalmának elillanását glicerin- vagy higanyfürdő alatt végzett feltárással akadályozták meg (RoEDDER 1972). KHITAROV et al. szárított levegővel történő evaporációt követően adszorbensen kötötte meg a fluidumzárvány illékony komponens-tartalmát (ROEDDER 1972). ELINSON vákuum alá helyezett fémgolyós mozsarat használt a zárványokban csapdázott fluidum kiszabadításához (RoEDDER 1972). Az 1960-as évektől kezdôdően a kutatók egyre nagyobb figyelmet fordítottak a fluidumzárványok termikus (BARKER 1965, PIPEROV \& PencheV 1973, BARKer \& SMith 1986, Kesler et al. 1986) és mechanikus (RoEDDER 1963, ABELL et al. 1970, Petersilie \& SöREnSEN 1970, RoEdDER 1972, WelHAN 1988) módon történő feltárására. A mechanikus feltárást kezdetben kétféle módon végezték, úgymint a mintadarab őrlése (Goguel 1963, Petersilie \& SöRENSEN 1970, ROEDDER 1972), illetve hidraulikus préselése (ROEDDER 1963, ANDREws \& GiBSON 1979, BRAY et al. 1991). Ezzel párhuzamosan egyre elterjedtebbé vált a mikroszkóp tárgyasztalára szerelhetô törôasztal (ROEDDER 1970 és az általa hivatkozott irodalmak), a húthető-fúthető tárgyasztal (ROEDDER 1962, 1963), valamint az ellenőrzött körülmények között létrehozott, ismert összetételű szintetikus fluidumzárványok (STERNER \& BODNAR 1984, BODNAR \& STERNER 1985) megjelenése, vizsgálata és azok kalibrációs célú alkalmazása a minél pontosabb eredmények biztosítása érdekében.

Az eltérô feltárási módszerek — termikus dekrepitáció, mechanikus őrlés, hidraulikus préselés — több hatás eredményeképpen gyakran eltérô eredményt szolgáltatnak. Ezt a jelenséget már az 1950-es években felismerték. A termikus dekrepitáció során a magas hőmérséklet hatására olyan kémiai reakciók játszódhatnak le, amelyek felülírhatják a zárványok csapdázta fluidum eredeti összetételét (WAHLER 1956, KESLER et al. 1986 és az általa hivatkozott irodalom, NORMAN \& SAWKINS 1987). Az őrléssel történő feltárás során a minta felülete jelentősen megnő, amely így a fluidumzárványokból felszabadult összetevők felületi megkötôdését eredményezheti (WAHLER 1956, PIPEROV \& PENCHEV 1973, BARKER \& TORKELSON 1975, NoRMAN \& SAWKINS 1987). A hidraulikus préselés révén a minta aprítása nem olyan mértékú, mint őrlés során, ezáltal a felületi adszorpció mértéke csökken, habár a fluidumzárvány együttesekből felszabaduló gőzök, gázok mennyisége is alacsonyabb (PiPerov \& Penchev 1973). Mindezek mellett a fluidumzárványok illó komponenseinek közvetlen feltárására — a lehetséges analitikai zavaró hatások kézben tartása mellett — a termikus és a mechanikai eljárás egyaránt alkalmazható (NORMAN \& SAWKINS 1987).

\section{A vizsgálatok során alkalmazott eszközök, módszerek}

\section{A gázanalizátor}

A cikkben bemutatott mérésekhez használt gázanalizátor az 1. ábrán látható. A rendszer egy PFEIFFER PrismaPlus $^{\mathrm{TM}}$ QMG220 típusú kvadrupól tömegspektrométerből, ehhez csatlakozó két pneumatikus (mechanikus) törőegységből, illetve a nagy vákuum előállításához szükséges rotációs és turbómolekuláris vákuumszivattyúkból áll. A mérések során a felszabadult illó komponenseket az elektronütközéses ionizációt követôen az 1-300 m/z (m/z töltésegységre jutó tömeg) tartományon vizsgálhatjuk. A tömegspektrométert a QUADERA® v4.5 szoftver vezérli. A múszer töróegységei, a tömegspektrométer és a központi váz állandó $100^{\circ} \mathrm{C}$ hômérsékletre felfütve üzemel, amely az alkalmazott vákuumtechnológia mellett a vizsgált mintán és a múszer fém vázszerkezetén adszorbeált komponensek eltávolítását elősegíti (NORMAN \& SAWKINS 1987, BARCLAY et al. 2000). Ez a hőmérséklet kellően alacsony, hogy törés közben a zárványokból felszabaduló szénhidrogének krakkolódása ne következzen be (BARCLAY et al. 2000), de elég magas, hogy hatására a zárványokban megemelkedett nyomás elősegítse a fluidumzárványok felnyílását amellett, hogy nem okozza azok kontrollálatlan termális dekrepi- 


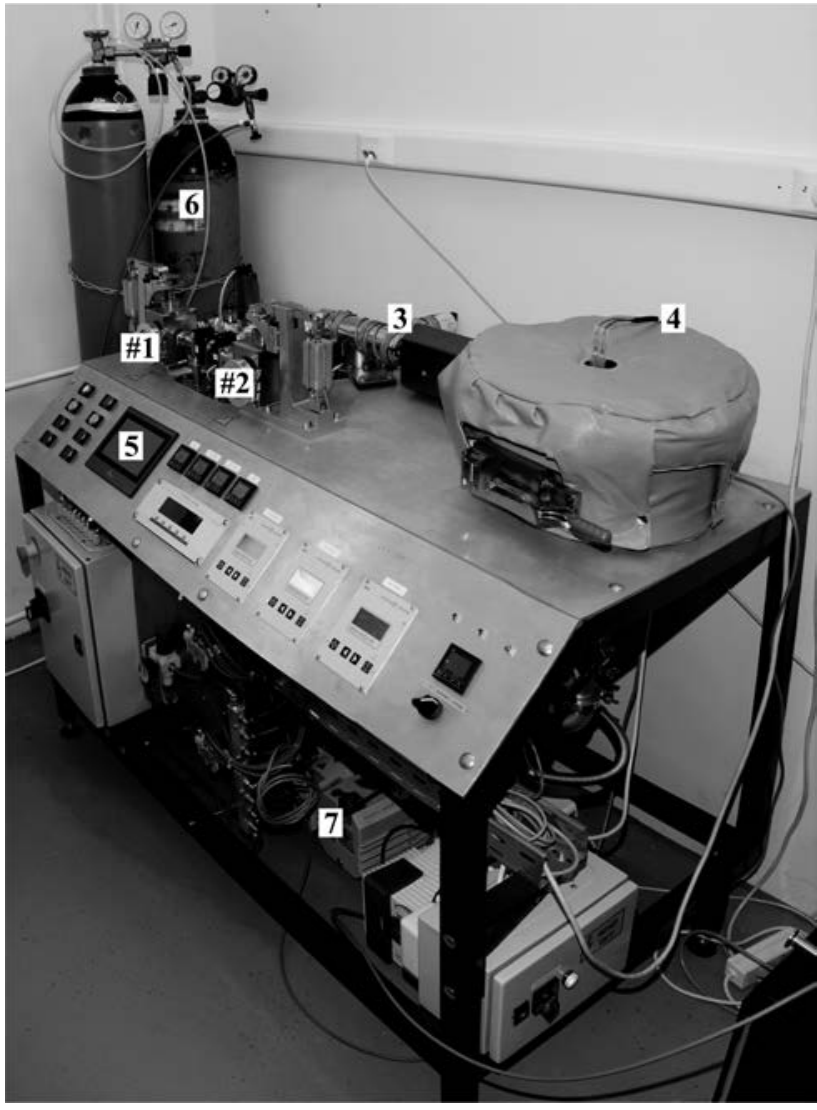

1. ábra. A gázanalizátor. Az alkalmazott jelölések: \#1 és \#2 - a pneumatikus törőegységek, 3 - a tömegspektrométer, 4 - vákuum tisztítószekrény, 5 kezelö felület, 6 - nitrogén palack, 7 - vákuum rendszer

Figure 1. The gas analyser. Legends: \#1 and \#2 - pneumatic crushers, 3 - mass spectrometer, 4 - vacuum chamber, 5 - user interface, 6 - nitrogen cylinder 7 vacuum system

tációját (KESLER et al. 1986 és az általa hivatkozott irodalom). A minták aprítását végző törôk pneumatikus egysége $785 \mathrm{~N}$ névleges erô kifejtésére képes. A törők ütésszáma 1-99 db, a törés időtartama, azaz a törō préselési ideje 1-99 ms tartományok között változtatható. A törők tisztítása, azok atmoszferikus nyomásra engedése nitrogén gáz (4.5 minőségú) alkalmazásával történik. Az egyes törôket és a tömegspektrométert vákuum szelepek választják el egymástól, amelyek a törôk esetében pneumatikusan, míg a tömegspektrométernél manuálisan (mechanikusan) múködtethetők. A mérés ,online" üzemmódban történik, amely során az egyes törôkben felaprított mintából felszabaduló gőzök-gázok, a szelepek nyitását követően, közvetlenül a tömegspektrométer mérési terébe áramlanak. A kőzetminták vizsgálata történhet előzetes szeparációt követően (pl. ásványfajták, méret stb. szerint), illetve anélkül, ez utóbbi esetben a mintában esetlegesen előforduló fluidumzárványokat együttesen vizsgáljuk. A szerves és szervetlen illó komponensek kvalitatív (minőségi) és félkvantitatív (fél-mennyiségi) vizsgálata előzetes kromatográfiás elválasztás nélkül történik.

A múszer észszerú és optimális használatának elengedhetetlen feltétele a minták megfelelő kiválasztása (OHM \& HANEFERD 2011), előkészítése, mennyisége és a megfelelő mérési protokoll alkalmazása. A különböző tömegspektro- metriás mérési eljárások esetében eltérő mintakezelés és minta-előkészítési eljárások alkalmazása (CHANNER et al. 1999, Liu et al. 2003, AhMEd \& GEORGE 2004, GEORGE et al. 2007), illetve mintamennyiség megválasztása ajánlott (BARKER 1965, Andrews \& Gibson 1979, Kesler et al. 1986, BRAY et al. 1991). A gázanalizátor egyedi felépítése és múködése miatt — a már említett irodalmi adatok, mintaelőkészítési és mérési eljárások mellett — szükségessé vált a múszer önálló, pontos mérési protokolljának kialakítása. Ennek érdekében különböző törési és tisztítási eljárásokat vizsgáltunk meg, és kidolgoztuk a berendezés múködéséhez optimális minta-előkészítési és vizsgálati eljárásrendet.

\section{A töréstesztek - a mintamennyiség és az optimális ütésszám meghatározása}

A töréstesztek elvégzésével lehetőség nyílik a törőegység, a mintamennyiség és az ütésszám meghatározására, amelyek ismeretében kellő bizonyossággal dönthetünk a vizsgált minták reprezentatív és reprodukálható vizsgálatáról. A teszteket Retsch AS200 típusú szitával, $50 \mathrm{~Hz}$ frekvencián, 5 perces szitálási idővel és 0-45-63-125-250 $\mu \mathrm{m}$ méretû́ szitasorral végeztük. A vizsgálatokhoz előzetesen 250-500 $\mu \mathrm{m}$-es mérettartományra szitált, analitikai tisztaságú kvarchomokot (Molar Chemicals Kft, 0,1-0,8 mm mérettartomány, CAS: 14808-60-7, EINECS: 238-8784) és a gázanalizátor törőit használtuk 1 másodperces préselési idővel.

A törési eljárást a törésszám emelésével, illetve növekvő mintamennyiséggel végeztük. A törésszám $25 \mathrm{db}$ ütéssel emelkedett (25-50-75 és $99 \mathrm{db}$ ) és az egyes sorozatok alkalmával 0,5-1,0-1,5-2,0 és 2,5 g szitált kvarchomokot törtünk, majd a tört minták újbóli szitálását és az egyes szemcsefrakciók tömegmérését végeztük el. Megvizsgáltuk a tört minta mennyiségének alakulását a préselési idő változtatásával, amit a törőfejek mintán tartásának idejével módosítottunk. Ennek érdekében mindkét törőt $50 \mathrm{db}$ és $75 \mathrm{db}$ ütésszámmal, illetve 1, 5 és 10 másodperces préselési idôvel múködtettük (2. ábra).

A törés hatékonysága a törést követően mért 250 um-nél kisebb átmérőjű szemcsefrakciók tömegének és a teljes minta tömegének a hányadosa, annak százalékban kifejezett értéke.

$$
X=\frac{\beta+\gamma+\delta+\varepsilon}{\alpha+\beta+\gamma+\delta+\varepsilon} \times 100
$$

Ahol [X\%] - a törés hatékonysága, $\alpha$ - a 250-500 $\mu$ mes, $\beta$ - a 125-250 $\mu \mathrm{m}$-es, $\gamma$ - a 63-125 $\mu \mathrm{m}$-es, $\delta$ - a 45-63 $\mu \mathrm{m}$-es és $\varepsilon-\mathrm{a} 0-45 \mu \mathrm{m}$-es szemcsefrakció törést követően mért mennyisége.

Statisztikai módszerekkel (t- és f-próba) megvizsgáltuk a törônként megfelelő sorozatok korrelációját, azaz hogy a törők azonos sorozatainak törési hatékonyság értékei azonosnak tekinthetőek-e. A kiindulási kvarc szemcsemérete, mennyisége, az ütésszám, a préselési idő és a pneumatikus egységek által kifejtett erő a tesztek során mindig azonos 


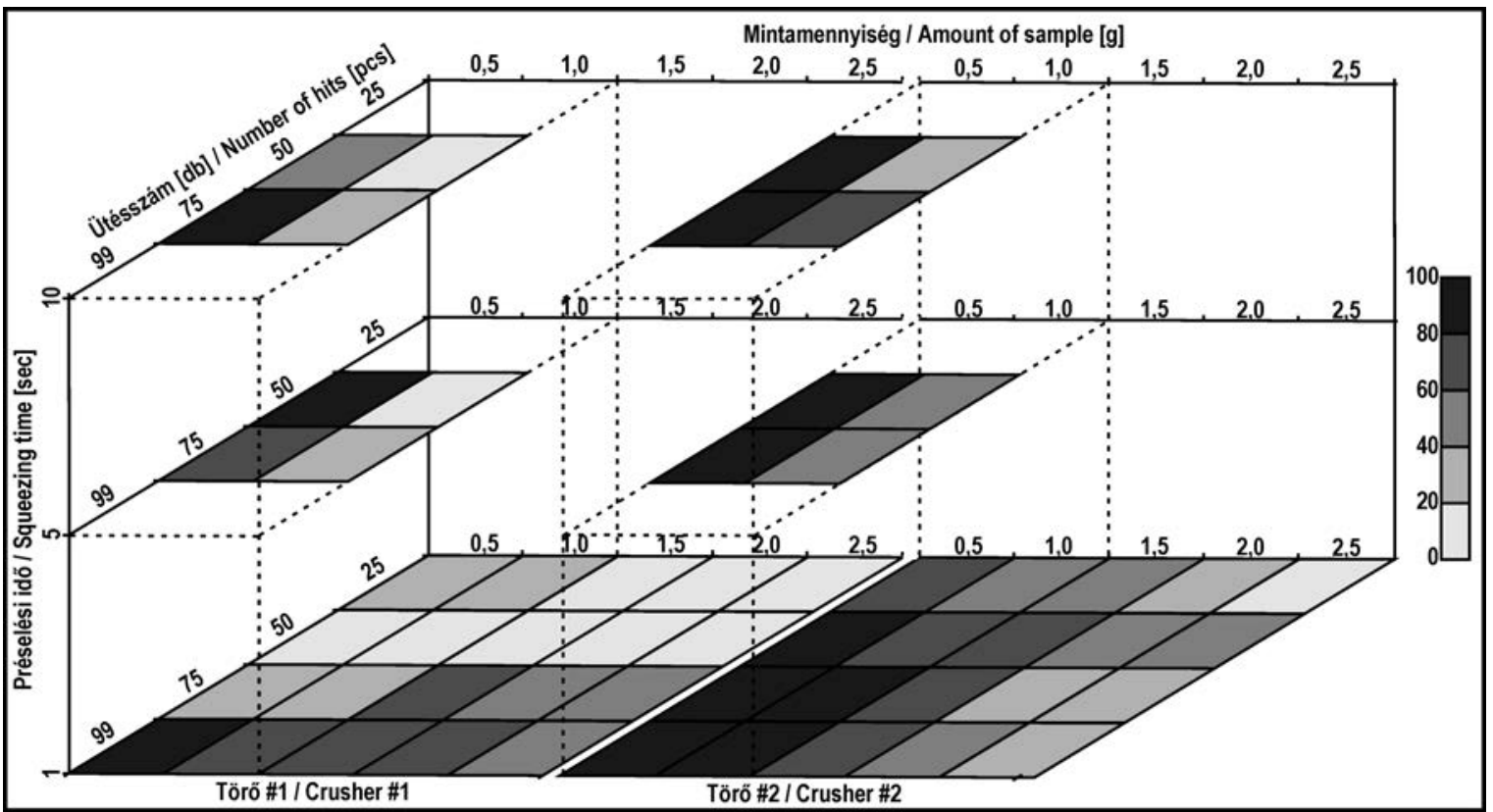

2. ábra. A töréstesztek során vizsgált változók és a számított törési hatékonyság értékek. A hatékonyság értékei a százalékos rangsor szerint színezettek

Figure 2. The investigated variables during crushing tests and the calculated efficiency values. The efficiencies are colored according to their percent ranking

volt. A vizsgálat során a két törôt függetlennek tekintettük és törőnként a tört kvarcszemcsék adott szemcseméretéhez tartozó mintamennyiség átlagát és szórását vettük figyelembe. Az eljárás során $95 \%$-os és $90 \%$-os konfidencia intervallumon vizsgáltuk az egyes töréses sorozatokat.

A gázanalizátor üzemeltetése során a törők pneumatikus egységének közvetlen mérésére a múszer kialakí- tása révén nincs lehetôség, ezért azonos anyagú és dimenziójú ólomszeletek préselését végeztük el mindkét törővel, és azok alakváltozását mértük egy darab 10 másodpercig tartó préselést követően. A tömör ólomszeletek magasságát (h) és átmérójét (d) mértük, majd azok területét (A) és fajlagos nyúlását $(\varepsilon)$ számoltuk a préselés előtt és után (3. ábra).

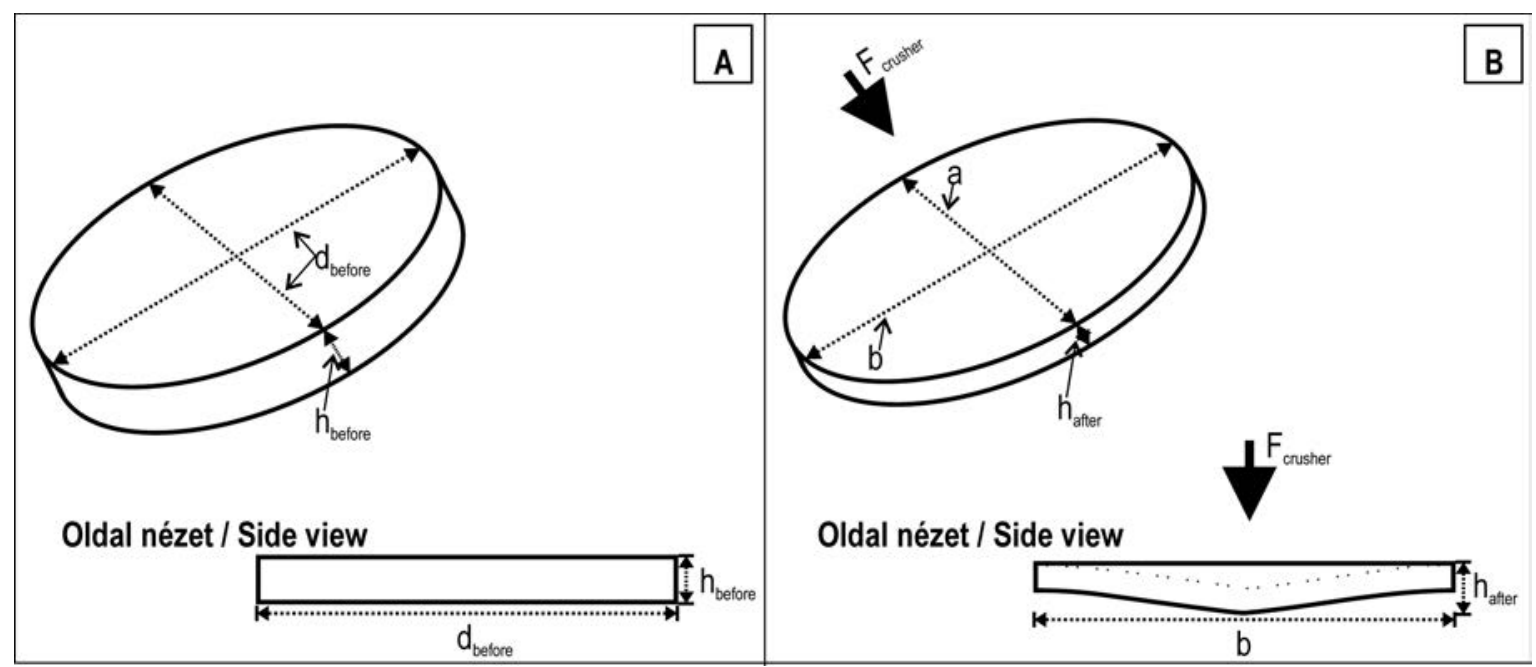

3. ábra. Az ólomszeletek sematikusan ábrázolva (A) préselés előtt és (B) préselés után. Préselést kővetően az ólom tesztdarab alakja igazodik a törőfej kúpos (szaggatott vonallal jelölve) és a mintatartó homorú alakjához

Az alkalmazott jelölések: $\mathrm{h}$ - a tesztdarab magassága a préselés előtt vagy után az indexnek megfelelően, $\mathrm{d}$ - a tesztdarab átmérỏje a préselés előtt, a és b - a tesztdarab tengelyei a préselést követően, $\mathrm{F}_{\text {crusher }}-\mathrm{a}$ törővel a tesztdarabra, kifejtette erő iránya

Figure 3. Schematic view of the lead test samples $(A)$ before and $(B)$ after squeezing them. Morphology of the lead test samples were accomodated to the conical shape of crushers (labelled by dashed line) and concave shape of sample holders

Applied labels are: $h$ - is the high of the samples before or after squeezing them according to their index, $d$-is the diameter of the samples before squeezing them, a and $b-$ are the axis of test sample after squeezing them, $F_{\text {crusher }}$-is the direction of applied force on the test sample by crusher 


\section{A tisztítási eljárások}

A kőzetminták kitermelése során alkalmazott öblítő folyadékok az ásványos alkotókkal közvetlenül érintkezve, azok felületén megkötődve, mint szennyezés jelentkeznek. Az adszorbeált komponensek eltávolítása kulcsfontosságú a vizsgálat során. Elsô lépésként — a törésteszteknél említett - analitikai tisztaságú kvarchomokot MI Swaco KCl vízbázisú polimer és Versaclean MKII olajbázisú fúróiszapokkal szennyeztük $80{ }^{\circ} \mathrm{C}$ hômérsékleten 90 percen keresztül. A szennyezett kvarchomok mintákat, azok szenynyezését követôen, mint a fúrásponton mosott, szárított furadékmintának tekintettük, amelyeket a minta-előkészítés során — a szennyezés típusának megfelelően — vizes vagy mosószeres tisztítás után szárítószekrényben $60{ }^{\circ} \mathrm{C}$ hőmérsékleten 24 órán keresztül szárítottuk. A tömegspektrometriás mérést minden egyes sorozatban szennyezetlen, vízbázisú és olajbázisú iszappal szennyezett kvarchomok mintákon végeztük el. Az egyes sorozatoknál a tömegspektrometriás mérést követően a szennyezetlen kvarc tömegspektrumának intenzitás értékei alapvonalat képeznek a szennye- zett minták tömegspektrumainak intenzitás értékeihez képest. A szennyezett és a szennyezetlen kvarchomok minták esetében eltérô minta-előkészítési eljárásokat alkalmaztunk, összesen öt sorozatban. Az „A” sorozatban nem történt minta-előkészítés, a „B” és a „C” sorozatok esetében a tömegspektrometriás mérést rendre 24 órás és 48 órás $100{ }^{\circ} \mathrm{C}$ hômérsékleten és $10^{-6}$ mbar nyomáson vákuumtisztításos előkészítés előzte meg. A „D” és az „E” jelú tesztek alkalmával a mintákat 1\% (pH 10-11) és 2\% (pH 12-13) töménységú rea-sol® detergens vizes oldatában, VWR típusú ultrahangos fürdőben, $40{ }^{\circ} \mathrm{C}$ hómérsékleten, 30 percen keresztül tisztítottuk. Majd desztillált vizes öblítést követôen 6 órán keresztül száradtak $60^{\circ} \mathrm{C}$ hômérsékletre beállított szárítószekrényben, amit 24 órás $100{ }^{\circ} \mathrm{C}$ hômérsékletû és $10^{-6}$ mbar nyomású vákuumtisztítás követett. A mérések során a gázanalizátor egyes számú törőjét 50 db ütésszámmal és ütésenként 1 másodperc préselési idővel használtuk. A felszabaduló illó komponensek tömegspektrumának felvétele az 1-100 m/z tartományon, scanning módban történt.

A kapott tömegspektrumok alapján meghatároztuk a tisztítási arányokat, amely során a megfelelő szennyezett

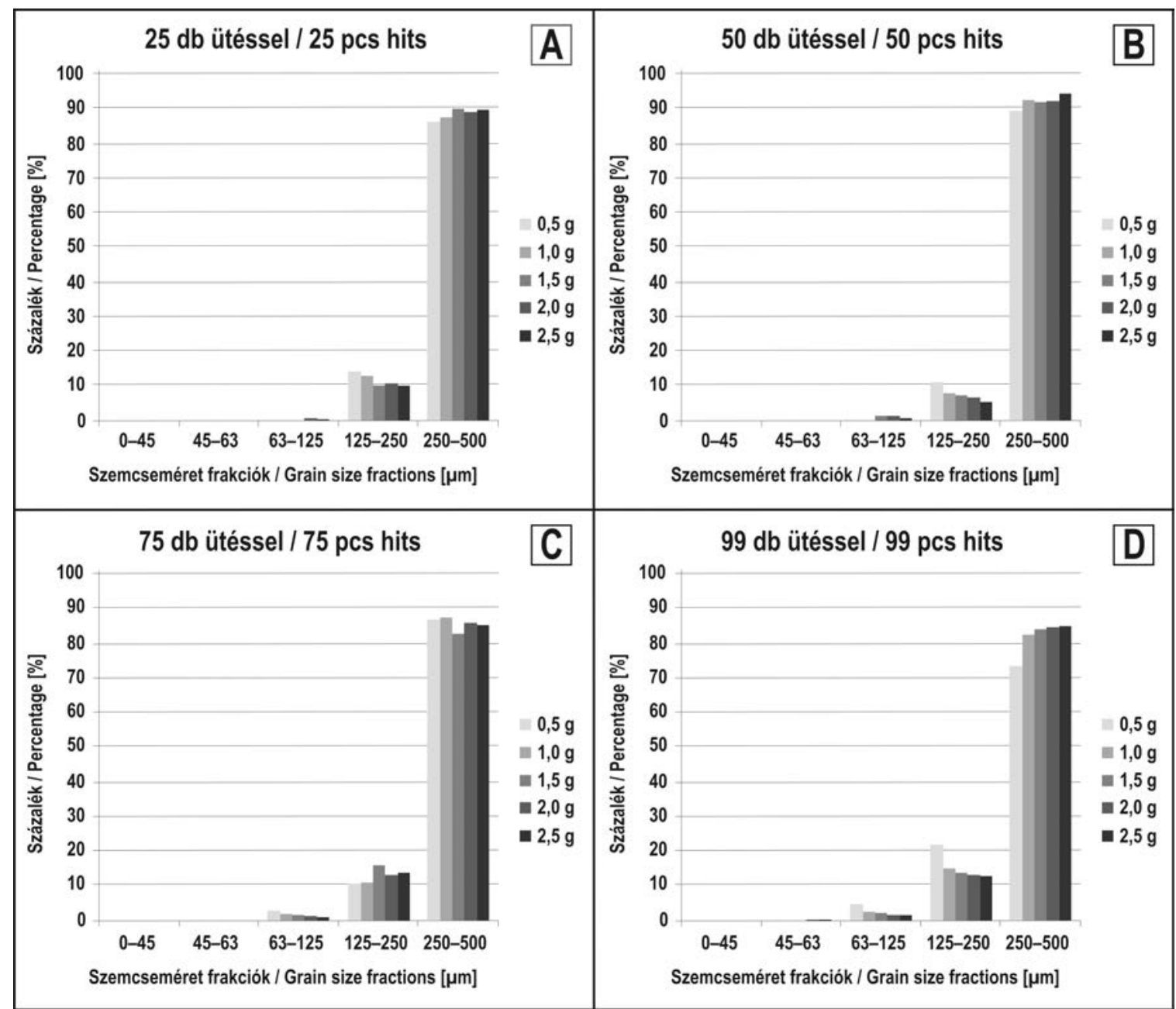

4. ábra. A szemcseméret eloszlás alakulása a mintamennyiség fél grammos emelésének függvényében, az egyes számú törőben, (A) $25 \mathrm{db}$; (B) 50 db; (C) 75 db és (D) 99 db ütésszámú sorozatokat követően

Figure 4. The grain size distribution according to the increasing amount of sample at (A) 25 pcs; (B) 50 pcs; (C) 75 pcs and (D) 99 pcs beats rate in the crusher\#1 
minta tömegspektrumának egyes $\mathrm{m} / \mathrm{z}$ értékeihez tartozó intenzitásértékeket a szennyezetlen kvarcminta tömegspektrumának azonos m/z értékeire normáltuk. Az adatok értelmezésekor a fluidumzárvány-sztratigráfia során vizsgált komponensek legjellemzőbb m/z értékeit vettük figyelembe (BARClay et al 2000, Dilley \& Norman 2007). Amennyiben a minták kellő tisztaságúak, akkor az egyes fragmentumokra számított tisztítási arányok értékei egy körüli értékeket vesznek fel.

\section{Eredmények}

\section{A töréstesztek}

A töréstesztek eredményeit - törônként lebontva - a szemcseméret-eloszlások példáján mutatjuk be, majd a törési hatékonyság alakulását tekintjük át az állandó ütésszám, a mintamennyiség és a préselés idôtartama szerint. Ezt követôen a törônként megfelelő sorozatok korrelációját vizsgáljuk meg. Végül a pneumatikus törőegységek közvetett terhelés mérését tárgyaljuk.
Az egyes számú törő használatakor 25 db ütést követően jellemzően a $125-250 \mu \mathrm{m}$ méretú szemcseméret frakció jelenik meg, azonban a mintamennyiség növelésével, 2,0 g felett, már a 63-125 $\mu \mathrm{m}$ méretú szemcsefrakció is megfigyelhetô (4. ábra, A). Az ütésszám emelésével a 63-125 $\mu \mathrm{m}$ méretú szemcseméret $50 \mathrm{db}$ ütést követően $1,5 \mathrm{~g}$ mintamennyiség mellett mérhetô (4. ábra, B). 75 db ütéssel a 63$125 \mu \mathrm{m}$ méretú szemcseméret frakció már $0,5 \mathrm{~g}$ minta esetében kimutatható (4. ábra, C). Az ütésszám további emelésével az aprózódás mértéke növekszik, azaz 2,0 g mintamennyiség 99 db ütésszámú törésekor már a 45-63 $\mu \mathrm{m}$ méretû́ szemcseméret frakció is mérhetô (4. ábra, $D)$. A kettes számú törốben a 63-125 $\mu \mathrm{m}$ méretú szemcseméret frakció a $25 \mathrm{db}$ ütésszámú sorozat esetében $0,5 \mathrm{~g}$ mintamennyiség törését követôen azonosítható (5. ábra, A), amelyet követôen annak a megjelenése általános marad a további sorozatokban is (5. ábra). A 45-63 $\mu \mathrm{m}$ méretú szemcseméret tartomány $75 \mathrm{db}$ ütést követően már $0,5 \mathrm{~g}$ tömegú kvarc törésénél mérhető (5. ábra, C).

Az egyes számú törő használatakor állandó mintamennyiséget használva, fél gramm minta törésénél, a 25-

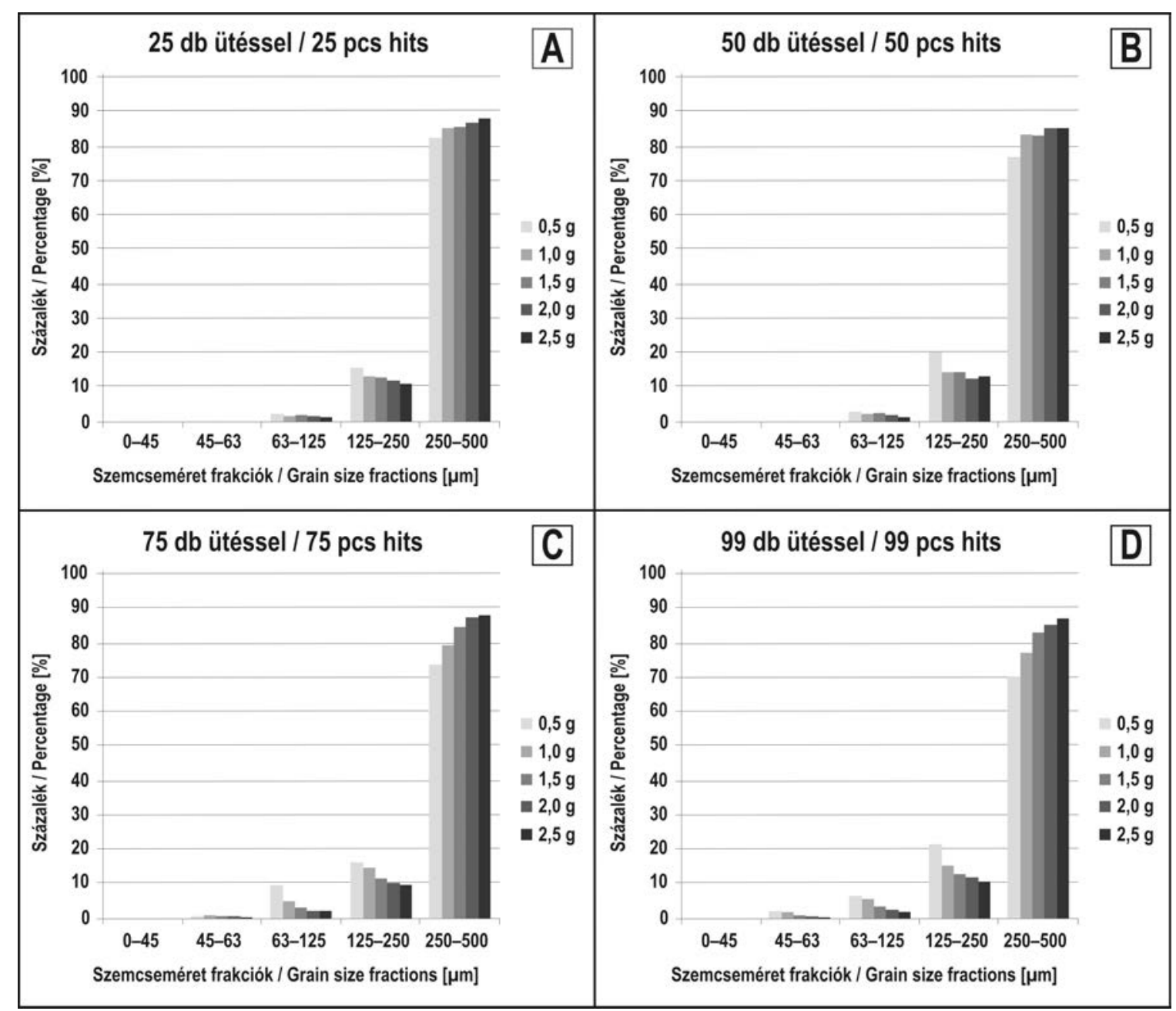

5. ábra. A szemcseméret-eloszlás alakulása a mintamennyiség fél grammos emelésének függvényében, a kettes számú törőben, (A) 25 db; (B) 50 $\mathrm{db}$; (C) $75 \mathrm{db}$ és (D) $99 \mathrm{db}$ ütésszámú sorozatokat követően

Figure 5. The grain size distribution according to the increasing amount of sample at (A) $25 \mathrm{pcs}$; (B) 50 pcs; (C) 75 pcs and (D) 99 pcs beats rate in the crusher \#2 
75 db ütésszámú sorozatokban a hatékonyság 11-14\%, de a maximális ütésszámú sorozat alkalmával $27 \%$ a törés hatékonysága (6. ábra). Az egy grammos mintamennyiségek törésekor az összes ütésszámú sorozatot figyelembe véve a zúzott minta aránya csökkenést mutat - 1-9\% hatékonyságkülönbséggel — a fél grammos sorozatokhoz képest. $25 \mathrm{db}$ ütést követően a hatékonyság $13 \%$ (6. ábra, A), $50 \mathrm{db}$ ütést követően $8 \%$ (6. ábra, B), 75 db ütést követően $12 \%$ (6. ábra, $C$ ) és $99 \mathrm{db}$ ütést követően $18 \%$ (6. ábra, D) a hatékonyság mértéke. A mintamennyiség további növelésével a $25 \mathrm{db}$ ütésszámú sorozatban a $250 \mu \mathrm{m}$-nél kisebb szemcseméret frakciók aránya csökken, amely állandó 10-11\% hatékonyságot mutat (6. ábra, A). Hasonló csökkenés figyelhető meg az 50 db ütésszámú sorozatban, ahol a mintamennyiség növekedését, rendre a $8 \%, 8 \%$ és $6 \%$-os törési hatékonyság követi (6. ábra, B). Nagyobb mintamennyiséggel és emelkedő ütésszámmal elvégzett sorozatok alkalmával nem mutatkozik lényeges eltérés a hatékonyságban, az 14-17\% (6. ábra, $C$ és D). A kettes számú törő esetében a törési sorozatok és azok emelkedő mintamennyiségével állandó csökkenô tendencia rajzolódik ki az aprított kvarcminta- mennyiségében, így a törés hatékonyságában (6. ábra). A kettes számú törôvel $0,5 \mathrm{~g}$ és $1,0 \mathrm{~g}$ mintamennyiség emelkedő ütésszámú törésekor rendre 18\%, 23\%, 27\% és 30\%, illetve $15 \%, 17 \%, 21 \%$ és $23 \%$ törési hatékonyság számítható (6. ábra, A és B). A mintamennyiséget tovább emelve, a törés hatékonysága az ütésszám növelésével nem fokozható $12-17 \%$ fölé (6. ábra, C és D).

Ezt követôen megvizsgáltuk, hogy miként alakul a hatékonyság a préselési idő változásával (7. ábra). Az egyes számú törőnél a törési hatékonyság 50 db ütést követôen $0,5 \mathrm{~g}$ és 1,0 g szitált kvarchomok használatakor növekszik az egy másodperces préselést követôen számított hatékonyságokhoz képest (7. ábra, A és B). A 0,5 grammos sorozat esetében a törés hatékonysága az 1,5 és 10 másodperces préselési idővel rendre $11 \%$, $18 \%$ és $15 \%$ (7. ábra, A). Az 1,0 grammos sorozatban ez $8 \%, 10 \%$ és $11 \%$ a préselési idő növekedésének függvényében (7. ábra, $B$ ). Amikor a $0,5 \mathrm{~g}$ mennyiségú mintát $75 \mathrm{db}$ ütéssel törtük, akkor a hatékonyság a préselési idő emelésével rendre 13\%, $18 \%$ és $22 \%$ értéket adott (7. ábra, C). Az 1,0 g mennyiségú kvarchomokkal elvégzett teszt alkalmával a hatékonyság az 1 másodpercnél tapasztalt 13\%

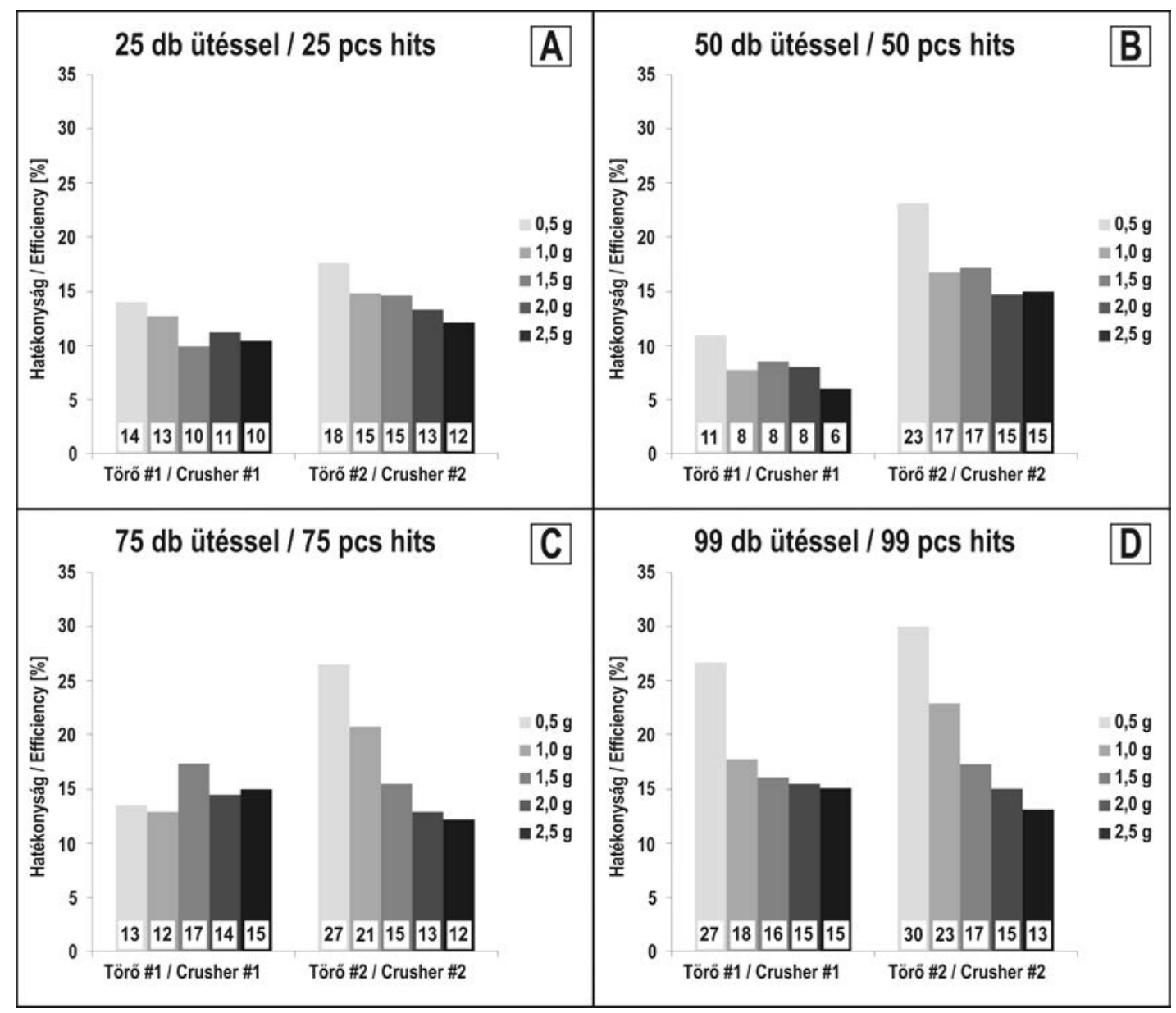

6. ábra. A törés hatékonyságának alakulása az egyes törőknek megfelelően a mintamennyiség fél grammos emelésének függvényében, (A) $25 \mathrm{db}$; (B) $50 \mathrm{db}$; (C) $75 \mathrm{db}$ és (D) $99 \mathrm{db}$ ütésszámú sorozatokat követően. Az oszlopdiagramokon a törési hatékonyság egész számra kerekített százalékos értékei olvashatók

Figure 6. The crushing efficiency according to the increasing amount of sample at (A) 25 pcs; (B) 50 pcs; (C) 75 pcs and (D) 99 pcs beats rate in the crushers. The efficiency values are written on the bar graphs as rounded integers 


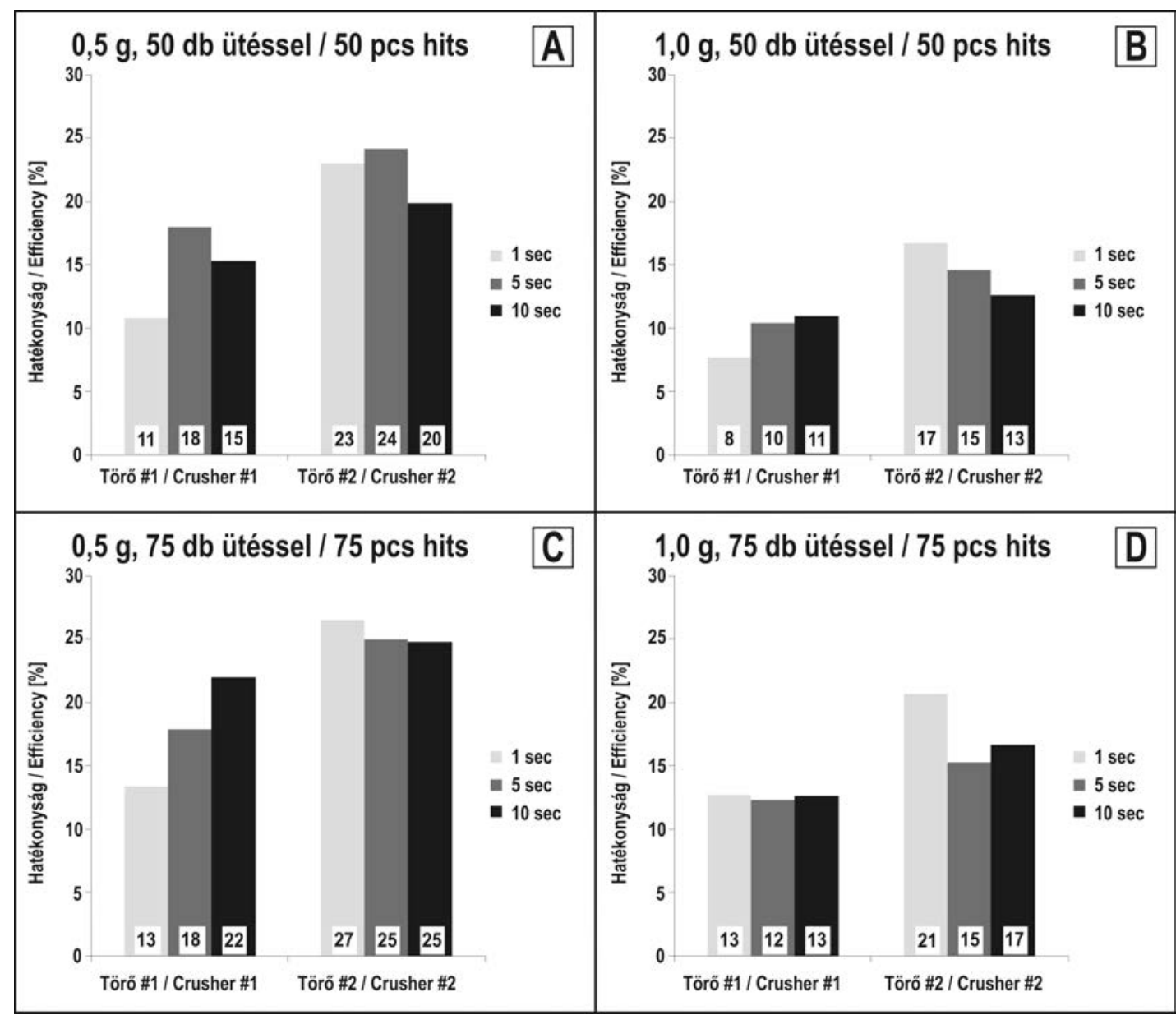

7. ábra. A törés hatékonyságának alakulása a préselés időtartamának növelésével, $50 \mathrm{db}$ ütést követően (A) $0,5 \mathrm{~g}$ és (B) $1,0 \mathrm{~g}$ mintamennyiséget alkalmazva, illetve $75 \mathrm{db}$ ütéssel (C) $0,5 \mathrm{~g}$ és (D) $1,0 \mathrm{~g}$ mintamennyiséget használva mindkét törő esetében. Az oszlopdiagramokon a hatékonyság egész számra kerekített százalékos értékei olvashatók

Figure 7. The crushing efficiency according to the squeezing time at 50 pcs beats rate with (A) $0.5 \mathrm{~g}$ and (B) $1.0 \mathrm{~g}$ amount of sample, furthermore, at 75 pcs beats rate with $(C) 0.5 \mathrm{~g}$ and $(D) 1.0 \mathrm{~g}$ amount of sample in the crushers. The efficiency values are written on the bar graphs as rounded integers

értéktől nem mutat jelentős eltérést, $12 \%$, illetve 13\%-ot ér el a préselési idô növelésével (7. ábra, $D$ ).

A kettes számú törő használatakor a fentiektôl eltérő eredményeket kaptunk. 50 db ütés és $0,5 \mathrm{~g}$ mintamennyiség esetén a törés hatékonysága 1 másodpercnél $23 \%$, amely érték a préselési időt emelve $24 \%$-ot mutat, majd 20\%-ra csökken (7. ábra, A). Egy gramm mennyiséget $50 \mathrm{db}$ ütésszámmal törve a törés hatékonyság értéke rendre 17\%, 15\% és $13 \%$ (7. ábra, B). A 75 db ütésszámú sorozatot vizsgálva a törési hatékonyság értékei rendre $27 \%, 25 \%$ és $25 \%$, illetve $21 \%, 15 \%$ és $17 \%$-os értékeket vesznek fel (7. ábra, C és $D)$. Az utóbbi sorozatoknál a préselési idő növelésével közel állandó törési hatékonyság értékeket kaptunk, 25\% és $16 \%$ körül. Amennyiben a hatékonyság függvényében állítunk sorrendet az egyes törési ciklusok és azok mintamenynyiségei között (I. táblázat és 2. ábra), akkor kitûnik, hogy a $80 \%$ vagy a feletti normatív hatékonyság mindösszesen 12 sorozat esetében teljesül a megvizsgált 55 sorozatból.

Amennyiben a törőket egy adott mintasorozat mérése alkalmával párhuzamosan használjuk, szükséges megállapítani, hogy törőnként mely sorozatok — ütésszám, minta- mennyiség és préselési idő — korrelálhatóak egymással. Emiatt indokolttá vált a törési hatékonyság értékeinek statisztikai alapú (t- és f-próba) vizsgálata. A 25 db ütést követôen a 0,5 g-os, 2,0 g-os és 2,5 g-os, a 75 db ütés után az 1,0 g-os, és 1,5 g-os, míg a 99 db ütéssel ismételten a 1,5 g-os, 2,0 g-os és 2,5 g-os sorozatok tekinthetôk azonosnak 5\% szignifikancia szinten. Amennyiben a szignifikancia szintet 0,1 értékben választjuk meg, akkor az eddigiek kiegészülnek a 25 db ütésszámú sorozat 1,0 g-os és a 99 db ütésszámú sorozat esetén további kettő, a 0,5 g-os és 1,0 gos sorozatokkal. Összességében 20-20 sorozat törését követôen a két törô között mindösszesen 8 sorozat esetében van jelentős azonosság 5\% szignifikancia szinten, és további 3 sorozat tekinthető szignifikánsan azonosnak $10 \%$ szignifikancia szint mellett.

A gázanalizátor fejlesztése több ütemben valósult meg, így a múszer kezdetben csak egy törő egységgel volt szerelve. A múszerfejlesztés során utólag beépített második törőegység és a törőnként eltérő törési hatékonyságok ismeretében felmerült a kérdés azok eltérő múködésérôl, így a törôk eltérő hatékonyságú üzemelésérôl. A gázanalizátor 
I. táblázat. A számított törési hatékonyságok százalékos sorrendje. A sorozatok jelölésénél rendre a törőegység préselési idö - ütésszám - mintamennyiség jelölést követtük

Table I. Percent ranking of calculated crushing efficiencies. The labels of series are in order of cusher - squeezing time beating rate - amount of sample

\begin{tabular}{|c|c|c|c|c|c|}
\hline $\begin{array}{c}\text { Rangsoros } \\
\text { normativ } \\
\text { hatékonyság/ } \\
\text { Percent ranking } \\
{[\%]}\end{array}$ & $\begin{array}{c}\text { Sorozat / } \\
\text { Series }\end{array}$ & $\begin{array}{c}\text { Rangsoros } \\
\text { normativ } \\
\text { hatékonyság / } \\
\text { Percent ranking } \\
{[\%]}\end{array}$ & $\begin{array}{c}\text { Sorozat / } \\
\text { Series }\end{array}$ & $\begin{array}{c}\text { Rangsoros } \\
\text { normativ } \\
\text { hatékonyság / } \\
\text { Percent ranking } \\
{[\%]}\end{array}$ & $\begin{array}{c}\text { Sorozat / } \\
\text { Series }\end{array}$ \\
\hline 100,0 & $\# 2-1-99-0,5$ & 65,4 & $\# 2-10-75-1,0$ & 30,9 & $\# 2-1-75-2,0$ \\
\hline 98,1 & $\# 1-1-99-0,5$ & 63,6 & $\# 1-1-99-1,5$ & 29,0 & $\# 1-1-75-1,0$ \\
\hline 96,3 & $\# 2-1-75-0,5$ & 61,8 & $\# 2-1-75-1,5$ & 27,2 & $\# 1-10-75-1,0$ \\
\hline 94,5 & $\# 2-5-75-0,5$ & 60,0 & $\# 1-1-99-2,0$ & 25,4 & $\# 1-1-25-1,0$ \\
\hline 92,7 & $\# 2-10-75-0,5$ & 58,1 & $\# 1-10-50-0,5$ & 23,6 & $\# 2-10-50-1,0$ \\
\hline 90,9 & $\# 2-5-50-0,5$ & 56,3 & $\# 2-5-75-1,0$ & 21,8 & $\# 1-5-75-1,0$ \\
\hline 89,0 & $\# 2-1-50-0,5$ & 54,5 & $\# 1-1-99-2,5$ & 20,0 & $\# 2-1-75-2,5$ \\
\hline 87,2 & $\# 2-1-99-1,0$ & 52,7 & $\# 2-1-99-2,0$ & 18,1 & $\# 2-1-25-2,5$ \\
\hline 85,4 & $\# 1-10-75-0,5$ & 50,9 & $\# 1-1-75-2,5$ & 16,3 & $\# 1-1-25-2,0$ \\
\hline 83,6 & $\# 2-1-75-1,0$ & 49,0 & $\# 2-1-50-2,5$ & 14,5 & $\# 1-10-50-1,0$ \\
\hline 81,8 & $\# 2-10-50-0,5$ & 47,2 & $\# 2-1-25-1,0$ & 12,7 & $\# 1-1-50-0,5$ \\
\hline 80,0 & $\# 1-5-50-0,5$ & 45,4 & $\# 2-1-25-1,5$ & 10,9 & $\# 1-1-25-2,5$ \\
\hline 78,1 & $\# 1-5-75-0,5$ & 43,6 & $\# 2-5-50-1,0$ & 9,0 & $\# 1-5-50-1,0$ \\
\hline 76,3 & $\# 1-1-99-1,0$ & 41,8 & $\# 1-1-75-2,0$ & 7,2 & $\# 1-1-25-1,5$ \\
\hline 74,5 & $\# 2-1-25-0,5$ & 40,0 & $\# 2-1-50-2,0$ & 5,4 & $\# 1-1-50-1,5$ \\
\hline 72,7 & $\# 1-1-75-1,5$ & 38,1 & $\# 1-1-25-0,5$ & 3,6 & $\# 1-1-50-2,0$ \\
\hline 70,9 & $\# 2-1-99-1,5$ & 36,3 & $\# 1-1-75-0,5$ & 1,8 & $\# 1-1-50-1,0$ \\
\hline 69,0 & $\# 2-1-50-1,5$ & 34,5 & $\# 2-1-25-2,0$ & 0,0 & $\# 1-1-50-2,5$ \\
\hline 67,2 & $\# 2-1-50-1,0$ & 32,7 & $\# 2-1-99-2,5$ & & \\
\hline
\end{tabular}

üzemeltetése során a törók pneumatikus egységének közvetlen mérésére a múszer kialakítása révén nincs lehetőség, ezért azonos anyagú és dimenziójú ólomszeletek préselését végeztük el mindkét törôvel, és azok alakváltozását mértük egy darab 10 másodpercig tartó préselést követôen. A megvizsgált ólomszeletek átlagos magassága $2,6 \mathrm{~mm}$, amelyek szórása 0,04 mm volt, azok átlagos átméróje 6,6-6,7 mm,
0,05 mm-es szórással. Az ütést követôen a tesztdarabok minden mért dimenziója megváltozott. Az átmérók egy ellipszis tengelyének megfelelôen 0,16 és $0,20 \mathrm{~mm}$-rel megnyúltak. A nyúlás mértékéből és az eredeti átmérőkből számított fajlagos nyúlás, 0,024-0,030 értéket mutat mindkét törô esetében (II. táblázat). Az ólomszeletek préselését követôen, azok felszínén megjelenik a törőfejek csúcsának

II. táblázat. Az ólom mintadarabok méretei és azok alakváltozása

Table II. Morphological parameters of the lead test samples

\begin{tabular}{|c|c|c|c|c|c|c|c|c|c|c|c|c|}
\hline 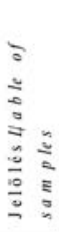 & \begin{tabular}{l}
$\vdots$ \\
$\vdots$ \\
$\vdots$ \\
$\vdots$ \\
0 \\
\hdashline \\
- \\
-
\end{tabular} & 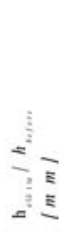 & 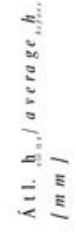 & $\begin{array}{l}=-1 \\
=1 \\
=1\end{array}$ & 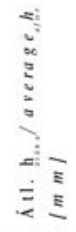 & 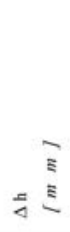 & 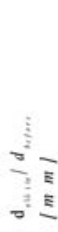 & 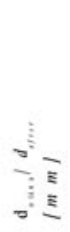 & $\begin{aligned} & \bar{E} \\
\square & \end{aligned}$ & 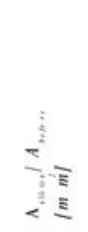 & 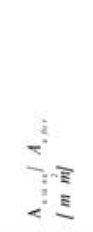 & $\varepsilon$ \\
\hline $1 / 1$ & \multirow{4}{*}{$\begin{array}{l}- \\
= \\
10 \\
:\end{array}$} & 2,60 & \multirow{7}{*}{2,625} & 2,82 & \multirow{7}{*}{2,825} & 0,22 & 6,72 & 6,88 & 0,16 & \multirow{7}{*}{141,87} & \multirow{7}{*}{149,56} & 0,024 \\
\hline $1 / 2$ & & 2,66 & & 2,82 & & 0,16 & 6,72 & 6,92 & 0,20 & & & 0,030 \\
\hline $1 / 3$ & & 2,60 & & 2,82 & & 0,22 & 6,72 & 6,88 & 0,16 & & & 0,024 \\
\hline $1 / 4$ & & 2,64 & & 2,84 & & 0,20 & 6,72 & 6,92 & 0,20 & & & 0,030 \\
\hline $2 / 1$ & \multirow{4}{*}{$\begin{array}{l}1 \\
* \\
10 \\
10 \\
10\end{array}$} & 2,56 & & 2,76 & & 0,20 & 6,62 & 6,78 & 0,16 & & & 0,024 \\
\hline $2 / 2$ & & 2,66 & & 2,82 & & 0,16 & 6,62 & 6,82 & 0,20 & & & 0,030 \\
\hline $2 / 3$ & & 2,58 & & 2,76 & & 0,18 & 6,62 & 6,78 & 0,16 & & & 0,024 \\
\hline $2 / 4$ & & 2,66 & 2,615 & 2,82 & 2,790 & 0,16 & 6,62 & 6,82 & 0,20 & 137,68 & 145,27 & 0,030 \\
\hline
\end{tabular}

Az egyes adatok számításának menete: $\Delta \mathrm{h}=\left(\mathrm{h}_{\text {utána }}-\mathrm{h}_{\text {elötte }}\right) ; \Delta \mathrm{d}=\left(\mathrm{d}_{\text {utána }}-\mathrm{d}_{\text {elôtte }}\right) ; \mathrm{A}_{\text {elôte }}=\mathrm{r}^{2} \pi ; \mathrm{A}_{\text {utána }}=\mathrm{ab} \pi ; \varepsilon=\Delta \mathrm{d} / \mathrm{d}_{\text {elötte }}$. Ahol $\mathrm{h}$ - a tesztdarab magassága a préselés elött vagy után az indexnek megfelelolően, $\Delta \mathrm{h}$ - a tesztdarab magasság változása, $\mathrm{d}$ a tesztdarab átmérője a préselés előtt vagy után az indexnek megfelelően, $\Delta \mathrm{d}$ - a tesztdarab átmérőjének változása, $\mathrm{A}$ - a tesztdarab területe a préselés előtt vagy után az indexnek megfelelően, $\mathrm{r}$ - a tesztdarab keresztmetszetének sugara, ab - a tesztdarab keresztmetszetében a féltengelyek szorzata, $\pi$ - konstans, $\varepsilon$ - fajlagos nyúlás

The used equations for calculating: $\Delta h=\left(h_{\text {affer }}-h_{\text {before }}\right) ; \Delta d=\left(d_{\text {affer }}-d_{\text {before }}\right) ; A_{\text {before }}=r^{2} \pi ; A_{\text {affer }}=a b \pi ; \varepsilon=\Delta d / d_{\text {before }}$ Where, $h-$ the high of the sample before or after squeezing it according to their index, $\Delta h$ - the high difference, $d$ - the diameter of the samples before or after squeezing it according to their index, $\Delta d$ - the diameter difference, $A$ - the area of the samples before or after squeezing it according to their index, $r$ - the radius of the sample before squeezing, ab-the multiplication of the half axis after squeezing, $\pi$ - a constant, $\varepsilon$ - the specific elongation 


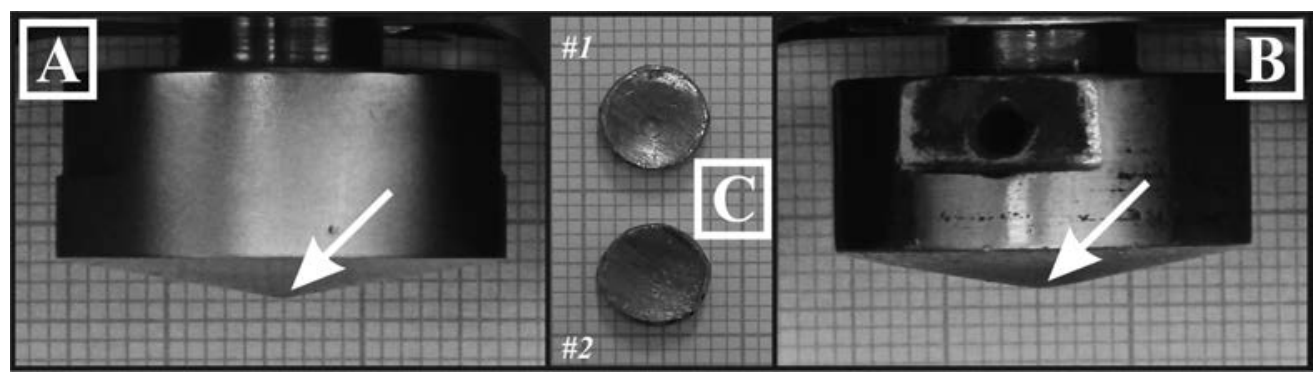

8. ábra. A gázanalizátor egyes számú (A), kettes számú (B) törőjének a feje és a deformált ólom mintadarabok a törők morfológiai negatívjával $(\mathrm{C})$

Figure 8. The heads of crushers at (A) crusher \#1, (B) crusher \#2 and (C) the deformed lead samples with the crusher head prints

morfológiai negatívja (8. ábra). Az egyes számú törőt alkalmazva annak feje jellegzetes, 1 mm átmérőjü pontban intenzívebben deformálja az ólomszeletet, ezzel szemben a kettes számú törô feje nem hagyott dominánsabb nyomot a mintadarabon, az egyenletesen homorú alakot vett fel $(8$. ábra, C). A törőfejeket összehasonlítva (8. ábra, A és B) elmondható, hogy az egyes számú törő feje kúposabb alakú, mint a kettes számú törőé.

\section{Tisztítási eljárások}

A minta-előkészítést nélkülöző minták tömegspektrumainak töltésegységre jutó tömeg szerinti intenzitás értékei folyamatos emelkedést mutatnak a szennyezetlen kvarcmintától, a vízbázisú fúróiszappal szennyezett mintákon keresztül az olajbázisú fúróiszappal szennyezett kvarcmintákig. Ezek alapján az erôteljesebb szennyezésnek kitett minták azonos fajlagos tömegú értékeihez tartozó ionáram-intenzitás értékei nagyobb intenzitással jelentkeznek (9. ábra, A). A vákuumtisztítási eljárások eredményeképpen a szenynyezett mintákból mért tömegspektrumok intenzitás-értékeinek eltérése csökken (9. ábra, $B$ és $C$ ), azok a $35 \mathrm{~m} / \mathrm{z}$ értékekig egyre inkább a tiszta kvarc tömegspektrumához hasonlítanak. A szennyezett és szennyezetlen minták megfelelő értékeinek hányadosából képzett tisztítási arányokat is figyelembe véve (10. ábra és III. táblázat), a magasabb m/z értékek esetében is csökkenés mutatkozik a vákuumtisztításos eljárást alkalmazva, illetve annak időtartamát növelve. A megfelelő tömegspektrumok esetében további intenzitásbeli különbségek csökkenése figyelhető meg, amennyiben a minták előkészítését lúgos mosási eljárással egészítjük ki. Mindezek következményeképpen a szennyezett minták tömegspektruma egybeesik a tiszta kvarc tömegspektrumával (9. ábra, D és E). Az egyes fragmentumokra számított tisztítási arányok értékeiben lényeges különbségek mutatkoznak a fúróiszap típusoknak megfelelően (10. ábra). A vízbázisú fúróiszappal szennyezett minták esetében számított tisztítási arányok egy körül ingadoznak (10. ábra, A), ezzel szemben az olajbázisú iszappal szennyezettek esetében ez nem teljesül (10. ábra, B). Az arány szignifikánsan 5-10-szeres, illetve 5-30-szoros eltérést mutat az eltérô szennyezéseknek megfelelően a magasabb $\mathrm{m} / \mathrm{z}$ értékek esetében. A számított vízbázisú és olajbázisú tisztítási arányok értékei egyhez közelítenek, amennyiben a vákuum- tisztításos eljárást mosással egészítjük ki. A leghatékonyabb tisztítás a 2\% töménységú ( $\mathrm{pH}$ 12-13) rea-sol® detergens vizes oldatának alkalmazásával érhető el (9. és 10. ábra).

\section{Az eredmények értelmezése}

A vizsgálatok során alkalmazott kvarcminta a kőzetminták polimineralikus ásványos összetételét tekintve egyszerúsítésnek számít, azonban számos lelőhelyrôl, mélyfúrásból származó kőzetminta megfelelő közelítésének tekinthető. A töréstesztek elvégzésének a célja az optimális törésszám és a mintamennyiség meghatározása volt, mivel e két paraméter ismerete jelentősen befolyásolja a törés során a minta aprózódásának a mértékét, ennélfogva a vizsgált mintában jelenlévő fluidumzárványok felnyílásának a valószínúségét. Ugyanakkor megmutatják, hogy nagyobb anyagmennyiség alkalmazása (amely reprezentatívabb a vizsgált ásványos összetevőre, kôzetre, mélységre stb.) és ezzel egyidejúleg a magasabb ütésszám használata valóban több könnyen illó komponens felszabadítását eredményezi-e a fluidumzárványokból.

A töréstesztek alkalmával az azonos ütésszámú sorozatok esetében jellemzô a magasabb törési hatékonyság a 0,5 g-os és 1,0 g-os sorozatokban, valamint a vizsgált kvarc mintamennyiségének növelésével közel állandó törési hatékonyság érhetô el (2. és 4-6. ábrák). Az aprózódott kvarc mennyiségének csökkenése mellett maximálisan 2-3\% eltérés figyelhető meg a törési hatékonyságban a mintamenynyiség emelését követve (6. ábra). Amennyiben a hatékonyság függvényében állítunk fel sorrendet az egyes törési ciklusok és azok mintamennyiségei között (2. ábra, és I. táblázat), akkor nyilvánvalóvá válik, hogy — bár a két törő alkalmazásakor eltérô mértékben — az ütésszám emelése pozitívan, míg a mintamennyiség növelése negatívan hat a törés hatékonyságára (2. és 6. ábrák). Az azonos ütésszámú sorozaton belül a mintamennyiség növelése csökkenti a hatékonyságot, amelyre hatással van a minta tömörödése. Az ütések során az ismétlődő aktív és nyugalmi periódusok alatt a szemcsék kis mértékben elcsúszhatnak egymáson, amely révén azok tovább aprózódnak, ami az egyre csökkenő szemcseméret megjelenésével igazolható (4. és 5. ábra). A növekvő mintamennyiséggel és a csökkenô szem- 


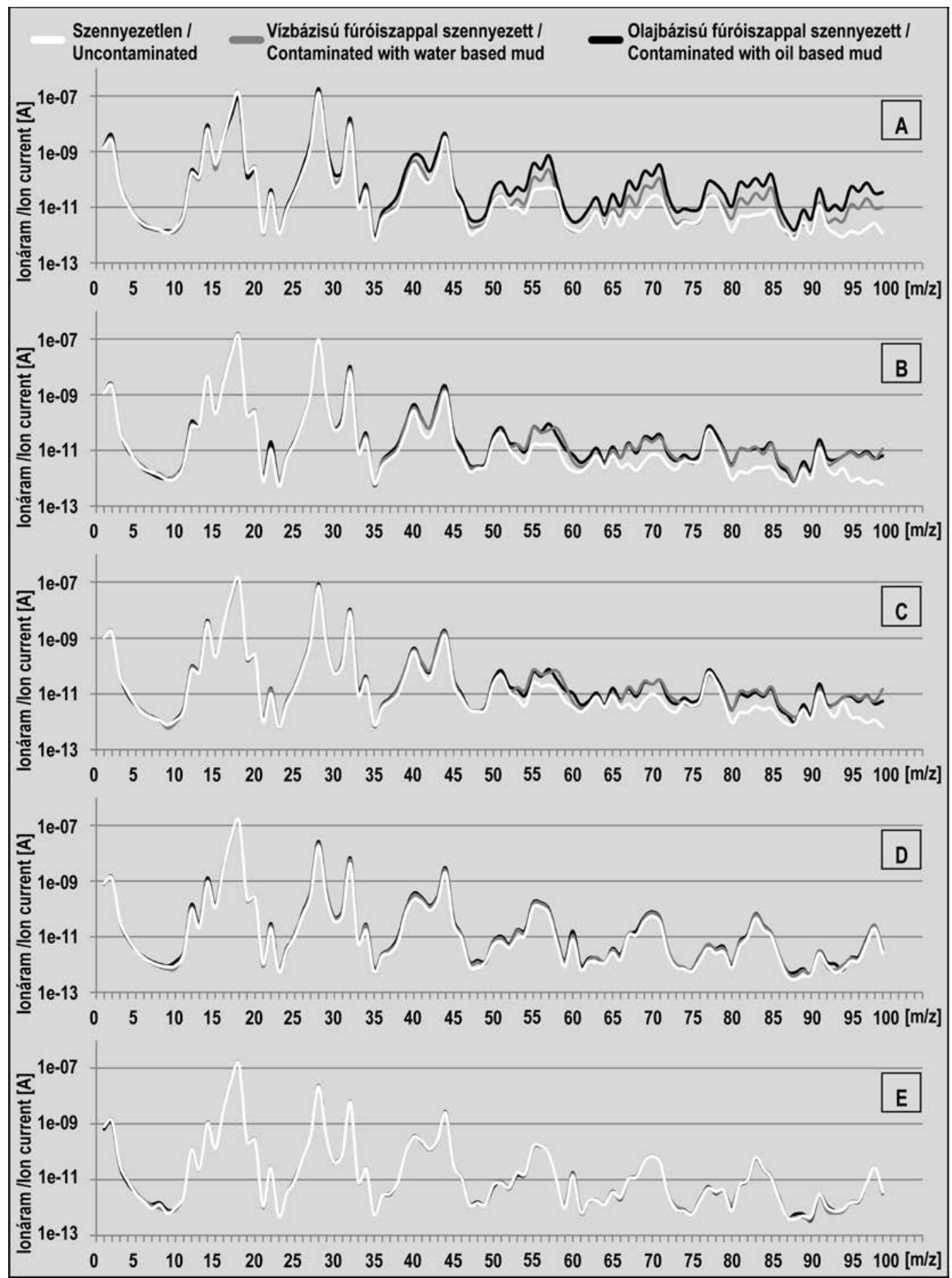

9. ábra. A tisztítási eljárásokat követően mért tömegspektrumok, ahol a mintát (A) előkészités nélkül; (B) 24 órás vákuumtisztitásos előkészitést követően; (C) 48 órás vákuumtisztitásos előkészitést követően; (D) 1\% töménységű és (E) 2\% töménységű rea-solß detergens vizes oldatos mosást és 24 órás vákuumtisztításos kezelést követően vizsgáltuk

Figure 9. The registered mass spectras at (A) without sample preparation, then using (B) 24 hours and (C) 48 hours vacuum cleaning.

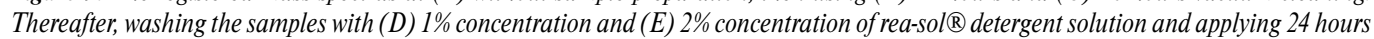
vacuum cleaning

csemérettel a szemcsék egyre szorosabban illeszkednek, azaz a szemcsék egymáson történô elmozdulásának a lehetősége csökken, ami a magasabb ütésszámú sorozat végére a tesztminta tömörödésében (,,pasztillázódásában”) nyilvánul meg. Emiatt az aprózódás egy adott ütésszámot követően blokkolódik.
A törőnként eltérő törési hatékonyság értékekben hasonlóság mutatkozik abban a tekintetben, hogy a kezdetben megfigyelhető növekvő hatékonyság a préselési idő növelésével tovább nem fokozható. Az ütésszám, a mintamenynyiség és a törésidő folyamatos növelésével csupán 1-2\% törési hatékonyság változás érhető el (7. ábra, $B$ és $D)$. 
III. táblázat. A tisztítási arányok a sorozatoknak megfelelően

Table III. The calculated cleaning proportions for water based and oil based ratios. The labels in the header are according to the applied cleaning procedures

\begin{tabular}{|c|c|c|c|c|c|c|c|c|c|c|}
\hline Sorozat / Series & \multicolumn{2}{|c|}{ A } & \multicolumn{2}{|c|}{ B } & \multicolumn{2}{|c|}{$\mathrm{C}$} & \multicolumn{2}{|c|}{$\mathrm{D}$} & \multicolumn{2}{|c|}{$\mathrm{E}$} \\
\hline & \multicolumn{10}{|c|}{ Tisztítási arányok / Cleaning proportions } \\
\hline $\mathrm{m} / \mathrm{z}$ & $\begin{array}{l}\text { Vizes / } \\
\text { WBM }\end{array}$ & $\begin{array}{c}\text { Olajos / } \\
\text { OBM }\end{array}$ & $\begin{array}{l}\text { Vizes / } \\
\text { WBM }\end{array}$ & \begin{tabular}{|c|} 
Olajos / \\
OBM
\end{tabular} & $\begin{array}{l}\text { Vizes / } \\
\text { WBM }\end{array}$ & $\begin{array}{c}\text { Olajos / } \\
\text { OBM }\end{array}$ & $\begin{array}{l}\text { Vizes / } \\
\text { WBM }\end{array}$ & $\begin{array}{c}\text { Olajos / } \\
\text { OBM }\end{array}$ & $\begin{array}{l}\text { Vizes / } \\
\text { WBM }\end{array}$ & $\begin{array}{c}\text { Olajos / } \\
\text { OBM }\end{array}$ \\
\hline 15 & 0,64 & 0,83 & 1,10 & 1,13 & 1,15 & 1,07 & 1,07 & 1,24 & 0,98 & 0,98 \\
\hline 29 & 0,87 & 1,41 & 0,95 & 1,06 & 1,18 & 1,23 & 1,26 & 1,48 & 1,03 & 1,01 \\
\hline 34 & 1,23 & 1,74 & 1,23 & 1,60 & 1,15 & 1,31 & 1,39 & 1,58 & 1,05 & 1,03 \\
\hline 44 & 0,87 & 1,32 & 1,19 & 1,66 & 1,23 & 1,42 & 1,29 & 1,54 & 1,01 & 1,07 \\
\hline 57 & 4,42 & 14,26 & 8,59 & 14,34 & 2,81 & 3,72 & 1,31 & 1,47 & 1,02 & 1,03 \\
\hline 71 & 4,85 & 14,96 & 4,63 & 5,86 & 4,81 & 4,62 & 1,31 & 1,44 & 1,02 & 1,00 \\
\hline 78 & 1,02 & 2,92 & 1,04 & 1,70 & 0,98 & 1,40 & 1,39 & 1,48 & 0,88 & 0,83 \\
\hline 85 & 6,01 & 18,54 & 6,83 & 7,38 & 5,82 & 5,06 & 1,24 & 1,28 & 1,14 & 0,98 \\
\hline 91 & 1,25 & 3,99 & 1,23 & 2,02 & 1,29 & 1,99 & 1,25 & 1,25 & 0,97 & 0,97 \\
\hline 99 & 8,73 & 29,92 & 19,06 & 10,85 & 22,97 & 8,55 & 1,33 & 1,39 & 0,88 & 0,86 \\
\hline
\end{tabular}

(A) minta-előkészítés nélkül; (B) 24 órás vákuumtisztításos előkészitést követően; (C) 48 órás vákuumtisztitásos előkészítést követően; (D) 1\%-os és (E) 2\%-os rea-sol ${ }^{\circledR}$ oldatos tisztítást és 24 órás vákuumtisztításos kezelést követően.

(A) - without sample preparation, then using $(B)-24$ hours and $(C)-48$ hours vacuum cleaning. Thereafter, washing the samples with

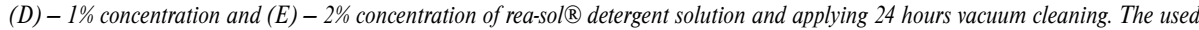
abbreviations are WBM - for contamination of water based mud and OBM - for contamination of oil based mud

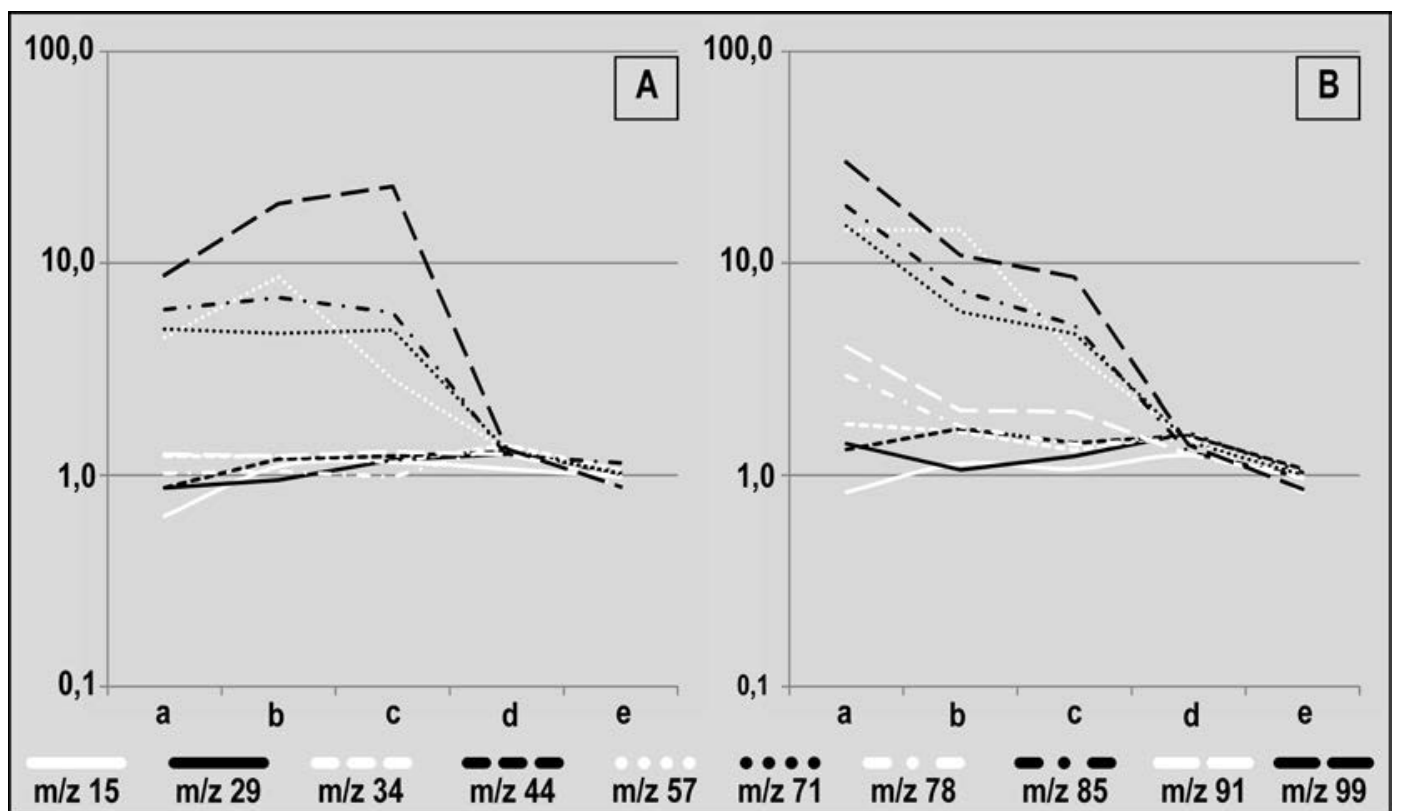

10. ábra. A III. táblázat $\mathrm{m} / \mathrm{z}$ értékeire számított (A) vízbázisú és (B) olajbázisú tisztítási arányok.

Az abcissza tengely jelölései: $\mathrm{a}-$ minta-előkészités nélkül, $\mathrm{b}-24$ órás vákuumtisztitásos előkészitést követően, $\mathrm{c}-48$ órás vákuumtisztitásos előkészitést követően, $d-1 \%$ töménységủ és e $-2 \%$ töménységủ rea-sol ${ }^{\circledR}$ detergens vizes oldatos mosást és 24 órás vákuumtisztításos kezelést követően

Figure 10. The calculated cleaning proportions for (A) water based ratios and (B) oil based ratios.

Legend of axis is according to the applied cleaning procedures: $a-$ without sample preparation, then using $b-24$ hours and $c-48$ hours vacuum cleaning Thereafter, washing the samples with $d-1 \%$ concentration and $-2 \%$ concentration of rea-sol ${ }^{\circledR}$ detergent solution and applying 24 hours vacuum cleaning

Általánosan elmondható, hogy az egyes számú törôt hoszszabb préselési idôtartammal múködtetve - alacsony mintamennyiség esetén - a hatékonyság mértéke fokozható. A kettes számú törô esetében a törés hatékonysága a törésszám, a mintamennyiség és a törésidő növelésével nem emelhetô (7. ábra). Az eltérô szemcseméret-eloszlások (4. és 5. ábra) és a törési hatékonyságok (2. és 6-7. ábra, I. táblázat) alapján, azonos feltételek mellett a két törő eltérő hatásfokon üzemel, ami hatással lehet a felrepesztett fluidumzárványok mennyiségére.
$\mathrm{Az}$ ólom tesztdarabok préselését követôen azok magasságában bekövetkezett változás a mintatartó homorú és a törófej domború alakja, továbbá a morfológiai paraméterek mérési módszere miatt mutat eltérést (3. ábra, és II. táblázat). A tesztminta alakja a préselődés során igazodott a törőfej és a mintatartó formájához, amelyek értelmében a préselés mértéke nem azonosítható az ólomminták függőleges tengelyének irányában (3. ábra). Az átmérók mentén bekövetkezó azonos mértékú fajlagos nyúlás alapján megállapítható, hogy a törók pneumatikus egységének múködése során a minta- 
darabokra átadott erôk nagysága azonos (II. táblázat). A törőfejeket összehasonlítva (7. ábra, A és B) elmondható, hogy az egyes számú töró feje kis mértékben kúposabb alakú, mint a kettes számú törőé. A törőfejek szemmel látható, kis mértékú eltérését feltehetőleg a gázanalizátor többlépcsős fejlesztése, így a gyakoribb használatból eredố mechanikai deformáció, kopás okozza, amely révén a kopottabbnak tekinthetố kettes számú törố feje egyenletesebben tölti ki a mintatartóban rendelkezésre álló teret. A töréstesztek eredményének tükrében a törőfejek kismértékben eltérő alakja jelentős hatással van a minta aprózódásának mértékére.

Mindazonáltal a kvarcszemcséken azonos ütésszámmal, mintamennyiséggel és préselési idővel elvégzett töréstesztek alapján a pneumatikus töróegységeknek eltérő a törési hatékonysága. A törési hatékonyságok különbözőségét a törőfejek eltérô mértékú koptatottsága okozza. Ezek értelmében az eltérô törőfejekkel szerelt töróegységek felváltva történő alkalmazása még hosszabb mintasorozat, azaz nagyobb mintaszám esetében sem javasolt, mivel a felrepeszthetô fluidumzárványok mennyisége szoros kapcsolatban áll a zúzott minta mennyiségével, azaz a törési hatékonysággal.

A tömegspektrométer ipari felhasználása széleskörú, azonban az önálló tömegspektrometriás mérési módszeren alapuló fluidumzárvány-sztratigráfia leginkább a geotermikus és a szénhidrogén iparban terjedt el. Bármely fúrástechnológiai eljárás során a felfúrt kőzet felszínre hozatalakor úgynevezett fúróiszapot, azaz öblítô közeget alkalmaznak, amely lehet gáz, gôz, hab vagy folyadék állapotú (GROwCOCK $\&$ HARVEY 2005). Ezek közül a legelterjedtebben alkalmazott a folyékony öblítő közeg, amelyek két fő csoportba tartoznak, víz-, illetve olajbázisú iszapok. Az utóbbi fúróiszap típust, annak a vízbázisú iszappal szembeni jobb kenőképessége, hőtúrőképessége és egyes kôzettípusokkal (kősó, anhidrit, agyag) szembeni alacsonyabb reaktivitása miatt alkalmazzák (DARLEY \& GRAY 1988). Mélyfúrás során felaprított kőzet a fúróiszappal közvetlenül érintkezve elkerülhetetlenül szenynyezést szenved, amelynek hatása eltéró a használt fúróiszap típusától és az adott kôzet ásványos alkotóinak kémiai és fizikai tulajdonságaitól függően. Mindezek értelmében a kőzetminta szennyezettségének minimalizálása vagy annak megszüntetése lényeges analitikai szempont, mivel tömegspektrometriás mérési eljárással akár nanogramm mennyiségú komponens kimutatására is lehetôség nyílik (NoRMAN \& MusGrave 1994, SAlvi \& Williams-Jones 2003). A szennyezett minták vizsgálatával — célirányosan — a szemcsék felületén a szenynyező oldatokból megkötött komponensek mérhetőségét, továbbá a minta tisztíthatóságát határoztuk meg. A minta-elókészítés során vákuumtisztításos eljárást alkalmazva, illetve annak idôtartamát növelve a fúróiszappal szennyezett minták esetében az adszorpció mértéke csökkenthetô, viszont a minta felületi szennyezettsége nem szüntethető meg teljes mértékben. A minták elókészítését lúgos mosási eljárással kiegészítve, a szennyezett és a szennyezetlen minták tömegspektrumain látható intenzitáskülönbség további csökkentése érhetố el. A leghatékonyabb eljárás a $2 \%$ töménységú rea-sol® detergens vizes oldatával biztosított, aminek a segítségével az eredetileg szennyezett minták tömegspekt- ruma — a megvizsgált m/z értékekre — átlagosan 97-99\% pontossággal megegyezik a szennyezetlen minta tömegspektrumával (9. és 10. ábra, III. táblázat).

\section{Összefoglaló következtetések}

Munkánk során a Szegedi Tudományegyetem, Ásványtani, Geokémiai és Kőzettani Tanszékén többlépcsôs fejlesztési projekt keretében elkészült gázanalizátor furadékmintákra kidolgozott módszertani fejlesztését mutattuk be.

A töréstesztek elvégzésével meghatároztuk az egyes törók hatékonyságát, ezzel összefüggésben a mérésekhez szükséges optimális mintamennyiséget és ütésszámot. A tesztek alapján a tömegspektrometriás mérési eljáráson alapuló gázanalizátor alkalmazása során — a törőfejek jelenlegi kialakítása mellett — a kettes számú törôt alkalmazzuk. A furadékminta törésének fokozásához szükséges vizsgálati anyagmennyiség 0,5$1,0 \mathrm{~g}$, a mérések idôtartamát is figyelembe véve a zárványok felnyitásához szükséges a minimum 50 db ütésszám és az egy másodperces préselési idô. A gázanalizátorral elvégzett tömegspektrometriás mérést megelôzően a minták mosószeres, majd vákuumtisztításos kezelése elengedhetetlen a minta felületén megkötődött szerves vagy szervetlen eredetú szenynyezők megfelelő mértékú eltávolításához, amely így növeli az egy mintára fordított fajlagos vizsgálati idô hosszát és költségét.

Azonos alakú törőfejek alkalmazásával lehetőség nyílik a törőegységek felváltva történó alkalmazására, amely nagyobb mintaszám esetében jelentôsen lerövidíti a minták vizsgálatának az idejét. A törőfejek eltérô mértékú mechanikai kopása hatással van a törés hatékonyságára, amelynek értelmében elkerülhetetlen a hatékonyság idôszakos ellenőrzése, továbbá a törőfej kopófelületének ,újragondolása” és helyettesítése például wolfram-karbiddal.

A megvizsgált minta-előkészítési és mérési eljárásokat felhasználva a kôzetmintákban csapdázódott fluidumzárványok gáz- és illékonyanyag-tartalmának kémiai összetétele és azok fúrásszelvény mentén történő változásának összehasonlítása a tömegspektrometriás mérési eljáráson alapuló gázanalizátor felhasználásával megvalósítható. A megvizsgálható kőzetminták mintavételezése, azok kitermelést követő kezelése vagy tárolása nem befolyásolja a kőzetmintákba zárt fluidumzárványok kémiai összetételét. Ennek megfelelően, számos terület vizsgálata során — függetlenül a fúráspontok mélyítésének idópontjától - plusz információt biztosít a paleo-fluidumrendszer kémiai összetételéról, fázishatárokról vagy migrációról. Mindezen felül, a fúrómagokkal ellentétben a furadékminták általánosan rendelkezésre állnak a mélyfúrások kivitelezése során, amelyek vizsgálata gyorsan, akár több fúráspontra - medence léptékben — is kivitelezhetô.

\section{Köszönetnyilvánítás}

A gázanalizátor felhasználói ezúton is köszönik Dr. MiLota Katalin, Kiss Károly és Dr. Ricza Tamás (MOL 
Nyrt.) megértő támogatását és segítségét a berendezés építési periódusában. Köszönettel tartozunk Dr. GYŐRI
Orsolyának és egy anonim olvasónak a kézirat bírálata során végzett munkájáért.

\section{Irodalom — References}

Abell, P. I., Draffan, G. H., Eglinton, G., Hayes, J. M., MaXwell, J. R. \& Pillinger, C. T. 1970: Organic analysis of the returned lunar sample. - Science 167, 757-759. https://doi.org/10.1126/science.167.3918.757

Ahmed, M \& George, S. C. 2004: Changes in the molecular composition of crude oils during their preparation for GC and GC-MS analyses. — Organic Geochemistry 35, 137-155. https://doi.org/10.1016/j.orggeochem.2003.10.002

ANDREWS, F. F. \& GIBSON, E. K. 1979: Release and analysis of gases from geological sample. - American Mineralogist 64, $453-463$.

AzMEY, K. \& BlameY, N. J. F. 2013: Source of diagenetic fluids from fluid-inclusion gas ratios. — Chemical Geology 347, $246-254$. https://doi.org/10.1016/j.chemgeo.2013.04.011

Barclay, S. A., Worden, R. H., Parnell, J., Hall, S. M. \& Sterner, S. M. 2000: Assesment of fluid contacts and compartmentalization in sandstone reservoirs using fluid inclusions: an example from the Magnus oil field, North Sea. — AAPG Bulletin 84, 489-504. https://doi.org/10.1306/c9ebce2d-1735-11d7-8645000102c1865d

BARKER, C. G. 1965: Mass spectrometric analysis of the gas evolved from some heated natural minerals. — Nature 205, $1001-1002$. https://doi.org/10.1038/2051001a0

BARKER, C. \& SMith, M. P. 1986: Mass spectrometric determination of gases in individual fluid inclusions in natural minerals. Analytical Chemistry 58, 1330-1333. https://doi.org/10.1021/ac00298a013

BARKER, C. \& TORKELSTON, B. E. 1975: Gas adsorption on crushed quartz and basalt. — Geochimica et Cosmochimica Acta 39, $212-218$. https://doi.org/10.1016/0016-7037(75)90173-8

BLAMEY, N. J. F. 2012: Composition and evolution of crustal, geothermal and hydrothermal fluids interpreted using quantitative fluid inclusion gas analysis. - Journal of Geochemical Exploration 116-117, 17-27. https://doi.org/10.1016/j.gexplo.2012.03.001

BodnAR, R. J. \& STERnER, S. M. 1985: Synthetic fluid inclusions in natural quartz. II. Application to PVT studies. - Geochimica et Cosmochimica Acta 49, 1855-1859. https://doi.org/10.1016/0016-7037(85)90080-8

Bray, C. J., Spooner, E. T. C. \& Thomas, A. V. 1991: Fluid inclusion volatile analysis by heated crushing, on-line gas chromatography; applications to Archean fluids. — Journal of Geochemical Exploration 42, 167-193. https://doi.org/10.1016/0375-6742(91)90066-4

BREWSTER, C. \& HALL, D. 2001: Deep, geopressured gas accumulation and Fluid Inclusion Stratigraphy (FIS) signatures: exploration implications from the lower Miocene trend, Gulf of Mexico. - Houston Geological Sociaty Bulletin 43, 27-33.

Channer, D. M. DeR., Bray, C. J. \& Spooner, E. T. C. 1999: Integrated cation-anion/volatile fluid inclusion analysis by gas and ion chromatography; methodology and examples. - Chemical Geology 154, 59-82. https://doi.org/10.1016/s0009-2541(98)00124-7

DARLEY, H. C. H. \& GRAY, G. R. 1988: Composition and properties of drilling and completion fluids. — Gulf Professional Publishing, Houston, USA (ISBN: 0-87201-147-X), 654 p.

DAVY, H. 1822: On the state of water and aeriform matter in cavities found in certain crystals. — Philosophical Transactions of the Royal Society of London 112, 367-376. https://doi.org/10.1098/rstl.1822.0028

Dilley, L. M. \& NoRman, D. I. 2005: Using fluid inclusion stratigraphy analyses to distinguish producing wells from non-producing wells in the Coso Geothermal Field, California - Proceedings World Geothermal Congress 1-6.

Dilley, L. M. \& NoRMAN, D. I. 2007: Fluid Inclusion Stratigraphy, A new method for geothermal reservoir assessment, Energy Research and Development Division, Final project report. - CEC-500-2013-064, New Mexico Institute of Mining and Technology, California Energy Commision, $106 \mathrm{p}$.

George, S. C. \& Ahmed, M. 2002: Use of aromatic compound distributions to evaluate organic maturity of the Proterozoic middle Velkerri Formation, McArthur Basin, Australia. — In: KeEP, M. \& Moss, S. J. (eds): The Sedimentary Basins of Western Australia 3: Proceedings of the Petroleum Exploration Sociaty of Australia Symposium, Perth, WA., 253-270.

George, S. C., Lisk, M., EAdington, P. J. \& QuezadA, R. A. 2002: Evidence for an early, marine-sourced oil charge to the Bayu GasCondensate Field, Timor Sea. — In: KeEP, M. \& Moss, S. J. (eds): The Sedimentary Basins of Western Australia 3. Proceedings of the Petroleum Exploration Sociaty of Australia Symposium, Perth, WA., 465-474.

George, S. C., Volk, H. \& Ahmed, M. 2007: Geochemical analysis techniques and geological applications of oil-bearing fluid inclusions, with some Australian case studies. — Journal of Petroleum Science and Engineering 57, 119-138. https://doi.org/ 10.1016/j.petrol.2005.10.010

GoGUEL, R. 1963: Die chemishe Zusammensetzung ser in den Mineralen einiger Granite und ihrer Pegmatite eingeschlossenen Gase und Flüssigkeiten. — Geochemica et Cosmochimica Acta 27, 155-181. https://doi.org/10.1016/0016-7037(63)90056-5

GRANEY, J. R., KESLER, S. E. \& JONES, H. D. 1991: Application of gas analysis of jasperoid inclusion fluids to exploration for micron gold deposits. - Journal of Geochemical Exploration 42, 91-106. https://doi.org/10.1016/0375-6742(91)90061-x

Growcock, F. \& Harvey, T. 2005: Drilling fluids. - In: ASME Shale Shaker Commitee, Drilling Fluids Processing Handbook, Gulf Professional Publishing, Elsevier, Burlington, USA (ISBN: 0-7506-7775-9), 15-68. https://doi.org/10.1016/b978-075067775-2/50003-2

HART, B. S. \& STEEN, A. S. 2015: Programmed pyrolysis (Rock-Eval) data and shale paleoenvironmental analyses: A review. - Interpretation 3/1, SH41-SH58. https://doi.org/10.1190/INT-2014-0168.1

Hurai, V., Huraiová, M., Slobodnik, M. \& Thomas, R. 2015: Geofluids, Developments in Microthermometry, Spectroscopy, Thermodynamics, and Stable Isotopes. —Elsevier (ISBN: 978-0-12-803241-1), 490 p. https://doi.org/10.1016/B978-0-12-803241-1.09979-2

KeSLER, S. E., BodNAR, R. J. \& MERnAGH, T. P. 2013: Role of fluid and melt inclusion studies in geologic research. — Geofluids 13, 398-404. https://doi.org/10.1111/gfl.12055

Kesler, S. E., Haynes, P. S., Creech, M. Z. \& Gorman, J. A. 1986: Application of fluid inclusion and rock-gas analysis in mineral exploration. — Journal of Geochemical Exploration 25, 201-215. https://doi.org/10.1016/0375-6742(86)90014-2 
Lisk, M., George, S. C., Summons, R. E., Quezada R. A. \& O’Brien, G. W. 1996: Mapping hydrocarbon charge histories: detailed characterisation of the South Pepper oil field, Carnorvon Basin. - Australian Petroleum Production \& Exploration Association Journal 36, 445-464. https://doi.org/10.1071/aj95024

LiU, K., Eadington, P. \& Coghlan, D. 2003: Fluorescence evidence of polar hydrocarbon interaction on mineral surfaces and implications to alteration of reservoir wettability. - Journal of Petroleum Science and Engineering 39, $275-285$. https://doi.org/10.1016/s0920-4105(03)00068-8

Livsey, A., CARMody, S. \& RAHARJA, M. 2014: The use of fluid inclusion information to understand hydrocarbon charge history in the Sokang through, East Natuna Basin. - Proceedings, Indonesian Petroleum Association, Thirty-Eight Annual Convention \& Exhibition, IPA14-G-362, 362-379.

Miranda, J. A., Hall, D. L., O’brien, G .W., Phiukhao, W., Goldie Divko, L. M., Chao, J. C., Campi, M. J., Eid, R. \& Tingate, P. R. 2013: Fluid Inclusion stratigraphy in the Gippsland Basin: Implications for geological carbon storage. — Department of Primery Industries, Victoria, Australia (ISBN: 978-1-74326-408-9), 60 p.

Moore, J. N., Norman, D. I. \& KenNEDY, B. M. 2001: Fluid inclusion gas compositions from an active magmatic-hydrothermal system: a case study of the Geysers geothermal field, USA. — Chemical Geology 173, 3-30. https://doi.org/10.1016/s0009-2541(00)00265-5

MunZ, I. A. 2001: Petroleum inclusions in sedimentary basins: systematics, analytical methods and application. — Lithos 55, 195-212. https://doi.org/10.1016/s0024-4937(00)00045-1

Norman, D. I., Moore, J. N., YonaKa, B. \& Musgrave, J. 1996: Gaseous species in fluid inclusions: a tracer of fluids and indicator of fluid process. - Proceedings: Twenty-First Workshop on Geothermal Reservoir Engineering, Stanford Geothermal Program, Workshop Report SGP-TR-151, Stanford University, Stanford, California, 233-240.

Norman, D. I. \& Musgrave, J. A. 1994: N2-Ar-He compositions in fluid inclusions: Indicators of fluid source. - Geochimica et Cosmochimica Acta 58/3, 1119-1131. https://doi.org/10.1016/0016-7037(94)90576-2

Norman, D. I. \& SAWkins, F. J. 1987. Analysis of volatiles in fluid inclusions by mass spectrometry. — Chemical Geology 61, 1-10. https://doi.org/10.1016/0009-2541(87)90020-9

OHM, S. E. \& HANEFERD, H. 2011: Drilling conditions making wells unsuitable for fluid inclusion studies on drill cuttings. $-A A P G$ Bulletin 95, 537-558. https://doi.org/10.1306/08181010035

Pang, L. S. K., GEORGE, S. C. \& QueZADA, R. A. 1998: A study of the gross composition of oil-bearing fluid inclusions using high performance liquid chromatograhy. — Organic Geochemistry 29, 1149-1161. https://doi.org/10.1016/s0146-6380(98)00135-1

Parnell, J., Middleton, D., Honghan, C. \& Hall, D. 2001: The use of integrated fluid inclusion studies in constraining oil charge history and reservoir compartmentation: examples from the Jeanne d'Arc Basin, offshore Newfoundland. — Marine and Petroleum Geology 18, 535-549. https://doi.org/10.1016/s0264-8172(01)00018-6

Piperov, N. B. \& Penchev, N. P. 1973: A study on gas inclusions in minerals. Analysis of the gases from micro-inclusions in allanite. Geochimica et Cosmochimica Acta 37, 2075-2097. https://doi.org/10.1016/0016-7037(73)90009-4

Petersile, I. A. \& Sörensen, H. 1970: Hydrocarbon gases and bituminous substances in rocks from the Ilímaussaq alkaline intrusion, South Greenland. — Lithos 3, 59-76. https://doi.org/10.1016/0024-4937(70)90088-5

RoEDDER, E. 1962: Studies of fluid inclusions I: Low temperature application of dual-purpose freezing and heating stage. — Economic Geology 57, 1045-1061. https://doi.org/10.2113/gsecongeo.57.7.1045

RoEDDER, E. 1963: Studies of fluid inclusions II: Freezing data and their interpretation. - Economic Geology 58, 167-211. https://doi.org/10.2113/gsecongeo.58.2.167

ROEDDER, E. 1970: Application of an improved crushing microscope stage to studies of the gases in fluid inclusions. — Mineralogische und Petrographische Mitteilungen 50/1, 41-58.

ROEDDER, E. 1972: Composition of fluid inclusions. — United States Geological Survey Professional Paper 440-JJ, Washington, 199 p.

RoEdDER, E., Ingram, B. \& HALL,W. E. 1963: Studies of fluid inclusions III: Extraction and quantitative analysis of inclusions in the milligram range. - Economic Geology 58, 353-374. https://doi.org/10.2113/gsecongeo.58.3.353

SAlvi, S. \& Williams-Jones, A. E. 2003: Bulk analysis of volatiles in fluid inclusions. - In: SAMson, I., ANDERSON, A. \& MARSHALL, D. (eds): Fluid inclusions: Analysis and Interpretation. - Mineralogical Association of Canada, Canada, Short Course Series 32, (ISBN 0-921294-32-8), 247-278.

SAmson, I., Anderson, A. \& Marshall, D. 2003 (eds) Fluid inclusions: Analysis and Interpretation. — Mineralogial Assosiaction of Canada, Short Course Series 32, Vancouver, British Columbia, 370 p.

Schubert, F., Kóthay K., Dégi, J., M. Tóth, T., Bali, E., Szabó, Cs., Benkó, Zs. \& Zajacz, Z. 2007: A szakirodalomban használt fluidum- és olvadékzárványokkal kapcsolatos kifejezések és szimbólumok szótára. — Földtani Közlöny 137/1, 83-102.

Sorby, H. C., 1858. On the microscopic structure of crystals, indicating the origin of minerals and rocks. - Quarterly Journal of the Geological Society of London 14, 453-500. https://doi.org/10.1144/GSL.JGS.1858.014.01-02.44

STERnER, M. S. \& BoDNAR, R. J. 1984: Synthetic fluid inclusions in natural quartz I. Compositional types synthesized and applications to experimental geochemistry. — Geochimica et Cosmochimica Acta 48, 2659-2668. https://doi.org/10.1016/0016-7037(84)90314-4

Volk, H., George, S. C., Killops, S. D., Lisk, M., Ahmed, M. \& Aw QueZADA, R. 2002: The use of fluid inclusion oils to reconstruct the charge history of petroleum reservoirs — an example from the Taranaki Basin. — New Zealand Petroleum Conference Proceedings, Publicity Unit, Crown Minerals, Ministry of Economic Development, Wellington, New Zealand, 221-233.

WAHLER, W. 1956: Über die in Kristallen eingeschlossenen Flüssigkeiten und Gase. — Gechemica et Cosmochemica Acta 9, $105-135$. https://doi.org/10.1016/0016-7037(56)90064-3

WelHAN, J. A. 1988: Methane and hydrogen in mid-ocean-ridge basalt glases: analysis by vacuum crushing. — Canadian Journal of Earth Sciences 25, 38-48. https://doi.org/10.1139/e88-004

Wright, A. W. 1881: On the gaseous substances contained in the smoky quartz of Branchville. —American Journal of Science 123, 209216. https://doi.org/10.2475/ajs.s3-21.123.209

Kézirat beérkezett: 2017. 06. 23. 